\title{
Interpretation of Arctic aerosol properties using cluster analysis applied to observations in the Svalbard area
}

\author{
By R. TREFFEISEN ${ }^{1 *}$, A. HERBER ${ }^{2}$, J. STRÖM ${ }^{3}$, M. SHIOBARA ${ }^{4}$, T. YAMANOUCHI ${ }^{4}, \mathrm{~S}_{\text {. }}$ \\ YAMAGATA $^{5}$, K. HOLMÉN ${ }^{6}$, M. KRIEWS ${ }^{2}$ and O. SCHREMS ${ }^{2}$, ${ }^{1}$ Alfred Wegener Institut für Meeres- \\ und Polarforschung, Am Telegrafenberg A43, Postfach 600149, 14401 Potsdam, Germany; ${ }^{2}$ Alfred Wegener Institut für \\ Meeres- und Polarforschung, Postfach 120161, 27515 Bremerhaven, Germany; ${ }^{3}$ Institute for Applied Environmental \\ Research, Air-pollution Laboratory, Stockholm University, 10691 Stockholm, Sweden; ${ }^{4}$ National Institute of Polar \\ Research, 9-10 Kaga 1 chome, Itabashi-ku, Tokyo 173-8515, Japan; ${ }^{5}$ Hokkaido University, Graduate School of \\ Engineering, N13W8 Sapporo 060-8628, Japan; ${ }^{6}$ Norwegian Institute of Air Research, The Polar Environment Centre, \\ N-9296 Troms $\phi$, Norway
}

(Manuscript received 25 June 2003; in final form 28 June 2004)

\begin{abstract}
Atmospheric aerosols play an important role in global climate change, directly through radiative forcing and indirectly through their effect on cloud properties. Numerous measurements have been performed in the last three decades in order to characterize polar aerosols. Information about aerosol characteristics is needed to calculate induced changes in the Earth's heat balance. However, this forcing is highly variable in space and time. Accurate quantification of forcing by aerosols will require combined efforts, assimilating information from different sources such as satellite, aircraft and surface-based observations. Adding to the complexity of the problem is that the measurements themselves are often not directly comparable as they vary in spatial/temporal resolution and in the basic properties of the aerosol that they measure. Therefore it is desirable to close the gap between the differences in temporal and spatial resolution and coverage among the observational approaches. In order to keep the entire information content and to treat aerosol variability in a consistent and manageable way an approach has to be achieved which enables one to combine these data. This study presents one possibility for linking together a complex Arctic aerosol data set in terms of parameters, timescale and place of measurement as well as meteorological parameters. A cluster analysis was applied as a pattern recognition technique. The data set is classified in clusters and expressed in terms of mean statistical values, which represent the entire database and its variation. For this study, different time-series of microphysical, optical and chemical aerosol parameters as well as meteorological parameters were analysed. The database was obtained during an extensive aerosol measurement campaign, the ASTAR 2000 (Arctic Study of Tropospheric Aerosol and Radiation) field campaign, with coordinated simultaneous ground-based and airborne measurements in the vicinity of Spitsbergen (Svalbard). Furthermore, longterm measurements at two ground-based sites situated at different altitudes were incorporated into the analysis. The approach presented in this study allows the necessary linking of routine long-term measurements with short-term extensive observations. It also involves integration of intermittent vertical aerosol profile measurements. This is useful for many applications, especially in climate research where the required data coverage is large.
\end{abstract}

\section{Introduction}

The effects of aerosols on atmospheric radiation remain a major uncertainty in our understanding of past and present climates and in predicting the future climate. Directly, the particles influence the atmosphere by scattering and absorbing solar and terrestrial radiation. This may lead to heating or cooling depending on the aerosol properties, the surface albedo and the cloud cover (IPCC,

\footnotetext{
* Corresponding author.

e-mail: rtreff@awi-potsdam.de
}

2001). Indirectly, aerosols affect the radiation and water budgets of the atmosphere (e.g. Blanchet, 1989; Hegg et al., 1996). Based on current knowledge, it is expected that a major impact of an increase in anthropogenic greenhouse gases will be a warming of the polar regions (IPCC, 2001). So far it is not completely clear what the impact of Arctic aerosols will be on the climate. Over the past three decades studies of the characteristics of Arctic aerosols have demonstrated an increasing interest in this field.

The direct radiative effect of high Arctic aerosol loadings (Arctic haze) has been investigated by numerous 1-D radiative transfer model studies (e.g. Emery et al., 1992; Shaw et al., 
1993). All these studies showed a gain of solar radiation by absorption in the atmosphere of $2-20 \mathrm{~W} \mathrm{~m}^{-2}$ (as a daily mean value) and were associated with an atmospheric heating rate of $0.1-1.8 \mathrm{~K} \mathrm{~d}^{-1}$. Furthermore the short-wave solar net flux at the surface was reduced by $0.2-6 \mathrm{~W} \mathrm{~m}^{-2}$, which resulted in surface cooling. The calculated magnitudes were strongly dependent on the assumed optical aerosol properties (determined by the concentration, chemical composition, size number distribution and atmospheric humidity) as well as on the solar zenith angle and surface albedo. However, the evaluation of the direct and indirect climatic effect of Arctic aerosols requires the use of complex 3-D climate models. Investigations with global climate models (e.g. Blanchet, 1989) have indicated a regionally strong varying surface warming in the range of 1-2 K in the high Arctic.

Since Arctic haze was discovered and described in the 1950s to the 1980s a major scientific effort has been undertaken to increase our knowledge about Arctic aerosols. An overview of the history and early studies on Arctic haze can be found in Shaw (1995) and Barrie (1986). Chemical properties of Arctic aerosols have been measured in several locations ranging from Alaska to the Greenland region, the European Arctic and the Central Arctic Ocean (see e.g. Heintzenberg, 1981; Barrie and Barrie, 1990; Hopfer et al., 1994; Leck et al., 2001; Ricard et al., 2002, and references therein). Numerous investigations have been undertaken to understand the sources, occurrence and pathways of Arctic aerosols (e.g. Heidam, 1984; Harris and Kahl, 1994; Norman et al., 1999; MacDonald et al., 2000 and references therein). Some long-term records of Arctic aerosol properties are available (e.g. Bodhaine and Dutton, 1993; Polissar et al., 1999; Herber et al., 2002; Quinn et al., 2002).

Information on the vertical structure of Arctic aerosols is based on aircraft measurements. For a month each spring during 1983, 1986, 1989 and 1991, an aircraft was operated in the Arctic covering the region from Alaska to Norway to study Arctic haze, air chemistry and solar radiation issues (e.g. Clarke et al., 1984; Raatz and Schnell, 1984; Radke et al., 1984; Dutton et al., 1989; Parungo et al., 1990). Three German-Russian measuring campaigns during the spring and summer of 1994 and spring of 1995 provided an opportunity to investigate the pollution of the Arctic atmosphere (e.g. Leiterer et al., 1997). Arctic haze was analysed in different areas such as the Atlantic, Norwegian, Canadian and Russian Arctic. Horizontal and vertical variations of $\mathrm{O}_{3}, \mathrm{SO}_{2}$, peroxyacetyl nitrate (PAN), $\mathrm{HNO}_{3}$, nitrate, sulfate and ammonium concentrations were also determined by aircraft observations (e.g. Pueschel and Kinne, 1995; Dreiling and Jaenicke, 1995; Dreiling and Friedrich, 1997; Khattatov et al., 1997; Krasnova et al., 1997; Skouratov, 1997; Jaeschke et al., 1999). Furthermore, airborne observations took place during a ferry flight from Germany to Spitsbergen and during the course of an experiment in June and July 1984 (Heintzenberg et al., 1991).

The examples above show the immense effort given to investigation of Arctic aerosols. Despite this effort, the understanding on how various anthropogenic and natural aerosols are trans- ported from their sources to the Arctic troposphere and how this is influencing Arctic chemistry and climate is still far from complete. Moreover, knowledge of the microphysical, optical and chemical properties of Arctic aerosols and their variation is crucial for evaluating their effect on the radiative budget of the atmosphere. For climate assessment, measurements of Arctic aerosols are still neither particularly extensive nor optimally distributed in space and/or time. In an attempt to overcome this problem we have used a statistical method (hierarchical cluster analysis) in order to link together extensive short-term measurements with long-term observations. The goal of this paper is to provide future estimates for aerosol model input parameters covering time periods where aerosol measurements are limited to a routine long-term aerosol monitoring.

\section{Database}

The data set studied is composed of different physical and chemical aerosol parameters obtained in the Svalbard area for different time intervals as well as different places and is summarized in Table 1. The hierarchical cluster analysis (HCA) for all ground-based systems was performed for a daily arithmetic mean even though the timescale variability of aerosols can be much smaller. Arithmetic mean values were chosen because they present a stronger signal than daily median values and therefore they are better suited to this type of analysis. The focus of this paper was not to investigate short-term aerosol variations. The most important points for the chosen daily basis are the time interval of the long-term integrated aerosol optical depth measurements as well as the ground-based chemical components which are only available on a daily basis due to the long sampling time. Another point is our intention to combine the extensive ground-based observations with airborne measurements, which are only performed for selected days. It is assumed that they represent the vertical aerosol characteristics of a day under consideration. This aspect is important because in the future aerosol model input parameters for a regional climate model, HIRHAM, will be derived on the basis of the obtained results (e.g. Dethloff et al., 1996, 2002; Rinke et al., 2000; Dorn et al., 2003). Among other things the required aerosol model input parameters of HIRHAM have to be provided as vertical information.

The study presented here takes advantage of a large aerosol data set from the Svalbard area. The long-term aerosol variation was analysed on the basis of two different time-series (see Table 1 for details). First, an 11-yr observation record of integrated aerosol optical depth (AOD) from 1991 to 2001 from a sun photometer (polar day) and a star photometer (polar night) at $\mathrm{Ny}$-Ålesund $\left(78^{\circ} 55^{\prime} \mathrm{N}, 11^{\circ} 53^{\prime} \mathrm{E}\right)$ and second, the 3-yr data record of the scattering coefficient from Zeppelin Mountain $\left(78^{\circ} 54^{\prime} \mathrm{N}\right.$, $\left.11^{\circ} 53^{\prime} \mathrm{E}\right)$. The AOD measurements are described in detail in Herber et al. (2002) and were provided as daily mean values. The scattering coefficients were averaged to daily mean 
Table 1. Measurement site, instrumentation, data availability and parameters used for the performed cluster analysis

\begin{tabular}{|c|c|c|c|c|c|c|c|}
\hline \multirow[t]{2}{*}{ Site } & \multicolumn{2}{|c|}{ Geo-location } & \multirow{2}{*}{$\begin{array}{l}\text { Height } \\
\text { (m a.s.l.) }\end{array}$} & \multirow{2}{*}{$\begin{array}{l}\text { Instrumentation for } \\
\text { statistical analysis }\end{array}$} & \multirow[t]{2}{*}{ Data availability } & \multirow{2}{*}{$\begin{array}{l}\text { Time interval } \\
\text { investigated }\end{array}$} & \multirow{2}{*}{$\begin{array}{l}\text { Parameters included in } \\
\text { cluster analysis }\end{array}$} \\
\hline & Lat. & Long. & & & & & \\
\hline Koldewey & $78^{\circ} 55^{\prime} \mathrm{N}$ & $11^{\circ} 53^{\prime} \mathrm{E}$ & 11 & $\begin{array}{l}\text { Star/sun photometer } \\
\text { Meteorol. parameters } \\
\text { Trajectories }^{\mathrm{a}}\end{array}$ & $\begin{array}{l}1991-2001 \\
1991-2001 \\
1991-2001\end{array}$ & $\begin{array}{l}\text { Daily mean } \\
\text { Arithmetic value }\end{array}$ & $\begin{array}{l}\text { AOD at } 533 \text { and } 1028 \mathrm{~nm} \text {, } \\
\text { colour ratio: } \\
\text { AOD }(533 / 1028 \mathrm{~nm}) \\
\text { global radiation, pressure, } \\
\text { temp., RH, wind velocity, } \\
\text { trajectory start sector, } \\
\text { trajectory sector with } \\
\text { max. residence time }\end{array}$ \\
\hline Rabben & $78^{\circ} 55^{\prime} \mathrm{N}$ & $11^{\circ} 53^{\prime} \mathrm{E}$ & 11 & $\begin{array}{l}\text { 2-stage impactor } \\
\text { IN } \\
\text { OPC } \\
\text { Meteorol. parameters } \\
\text { Trajectories }^{\mathrm{a}}\end{array}$ & $\begin{array}{l}19 \text { Mar-22 Apr } 2000 \\
15 \text { Mar-21 Apr } 2000 \\
15 \text { Mar-21 Apr } 2000 \\
15 \text { Mar-21 Apr } 2000 \\
15 \text { Mar-21 Apr } 2000\end{array}$ & $\begin{array}{l}\text { Daily mean } \\
\text { Arithmetic value }\end{array}$ & $\begin{array}{l}\text { PNC, scattering } \\
\text { coeff. }(450,500,700 \mathrm{~nm}) \text {, } \\
\text { ratio of } 450 / 700 \mathrm{~nm} \text {, } \\
\text { global radiation, } \\
\text { pressure, temp., } \\
\text { RH, wind velocity, } \\
\text { trajectory start sector, } \\
\text { trajectory sector with } \\
\text { max. residence time, } \\
\text { chem. components }\end{array}$ \\
\hline $\begin{array}{l}\text { Zeppelin } \\
\text { Mountain }\end{array}$ & $78^{\circ} 54^{\prime} \mathrm{N}$ & $11^{\circ} 53^{\prime} \mathrm{E}$ & 475 & $\begin{array}{l}\text { IN } \\
\text { DMPS } \\
\text { Meteorol. parameters } \\
\text { Trajectories }^{\mathrm{a}}\end{array}$ & $\begin{array}{l}\text { May 1999-May } 2002 \\
15 \text { Mar-21 Apr } 2000 \\
\text { May 1999-May } 2002 \\
\text { May 1999-May } 2002\end{array}$ & $\begin{array}{l}\text { Daily mean } \\
\text { Arithmetic value }\end{array}$ & $\begin{array}{l}\text { Parameter lognormal } \\
\text { distribution, PNC, } \\
\text { scattering coeff. } \\
(450,500,700 \mathrm{~nm}) \text {, } \\
\text { ratio of } 450 / 700 \mathrm{~nm} \text {, } \\
\text { global radiation, pressure, } \\
\text { temp., RH, wind velocity, } \\
\text { trajectory start sector, } \\
\text { trajectory sector with } \\
\text { max. residence time }\end{array}$ \\
\hline Aircraft & See & Table 3 for & letails & $\begin{array}{l}\text { Sun photometer } \\
\text { IN } \\
\text { PSAP } \\
\text { OPC } \\
\text { Trajectories }^{c}\end{array}$ & $\begin{array}{l}\text { Different days } \\
\text { between } 15 \text { Mar and } \\
30 \text { Apr } 2000 \\
\text { (see Table 2) }\end{array}$ & $\begin{array}{l}\text { Averaged to the } \\
\text { height levels of } \\
\text { extinction } \\
\text { measurements of } \\
\text { each flight }\end{array}$ & $\begin{array}{l}\text { Extinction coeff., } \\
\text { absorption coeff., } \\
\text { scattering coeff., PNC, } \\
\text { RH, trajectory start } \\
\text { sector, trajectory sector } \\
\text { with max. residence } \\
\text { time, height }\end{array}$ \\
\hline
\end{tabular}

Abbreviations: IN, integrating nephelometer; OPC, optical particle counter; DMPS, differential mobility particle sizer; PSAP, particle soot/absorption photometer; $\mathrm{RH}$, relative humidity; PNC, particle number concentration.

${ }^{\mathrm{a}} 96 \mathrm{~h}$ backward trajectories were calculated for different height levels $(1500,3000$ and $5000 \mathrm{~m})$ at each day at 12:00 UT. Five sectors were used for classifying the trajectories. Sector $1:-15^{\circ}$ to $45^{\circ}$ (represents air masses coming from Europe); sector $2: 45^{\circ}$ to $150^{\circ}$ (represents air masses coming from Siberia); sector 3: $150^{\circ}$ to $-135^{\circ}$ (represents air masses coming over the North Pole); sector $4:-135^{\circ}$ to $-60^{\circ}$ (represents air masses from Canada); sector $5:-60^{\circ}$ to $-15^{\circ}$ (represents air masses from Greenland. Prior to the HCA each trajectory was grouped twice according to its starting sector and its sector of longest residence time. These two variables were incorporated into the HCA to represent the air mass history. ${ }^{\mathrm{b}} \mathrm{Chemical}$ species used for HCA4: $\mathrm{Al}, \mathrm{Mn}, \mathrm{Fe}, \mathrm{Na}, \mathrm{Mg}, \mathrm{K}, \mathrm{Na} / \mathrm{Mg}, \mathrm{Ti}, \mathrm{S}, \mathrm{Ni}, \mathrm{Co}, \mathrm{Cu}, \mathrm{Zn}, \mathrm{Cd}, \mathrm{Pb}$; sampling duration between 1 and 3 d. ${ }^{\mathrm{c}} 96 \mathrm{~h}$ backward trajectories were calculated for the middle of the corresponding extinction height level.

arithmetic values prior to the cluster analysis. The annual cycle of AOD is shown in Fig. 1a with typical maxima in March, April and May and minima during the winter, which reflects the fact that the Arctic is perturbed by anthropogenic aerosol sources, especially in late winter and spring. Taking into account the quite large error bars representing the internal monthly variation, this behaviour is also seen in the monthly mean values of the scattering coefficient (Fig. 1c). Figures $1 \mathrm{~b}$ and $1 \mathrm{~d}$ denote differences which might be assigned to a change in the aerosol characteristics (Ström et al., 2003). 

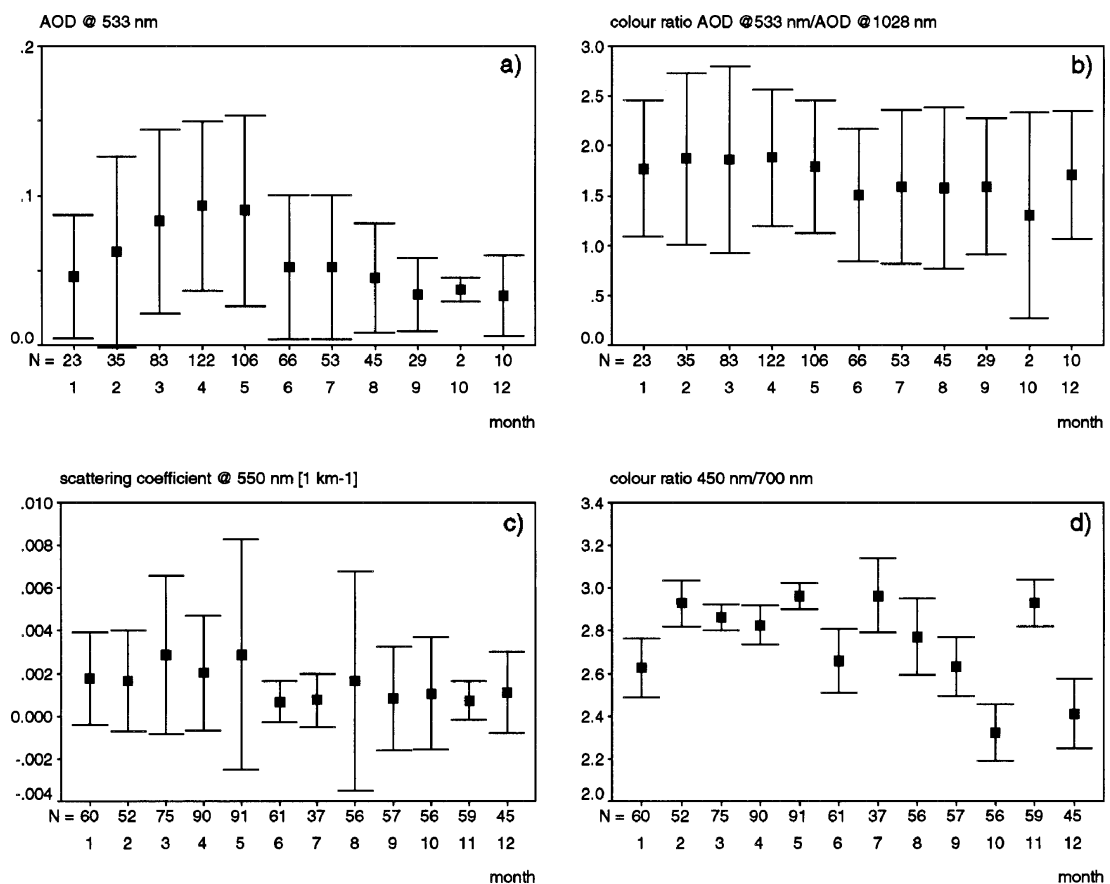

Fig 1. Monthly mean variation of the long-term database of the sun photometer measurements at Koldewey and the integrating nephelometer measurements at Zeppelin Mountain (error bars represent the monthly variation). For details on the database see Tables 1 and 2. (a) Monthly mean AOD from Koldewey. (b) AOD monthly mean colour ratio $533 \mathrm{~nm} / 1028 \mathrm{~nm}$. (c) Monthly mean scattering coefficient at $550 \mathrm{~nm}$ from Zeppelin Mountain. (d) Monthly mean colour ratio of the scattering coefficient $(459 \mathrm{~nm} / 700 \mathrm{~nm})$.
Furthermore, different short-term data sets were analysed, which were recorded by the Arctic Study of Tropospheric Aerosol and Radiation (ASTAR) 2000 campaign. This campaign provided extensive vertical measurements of microphysical, optical and chemical aerosol properties around the Svalbard area and simultaneously conducted aerosol measurements at two ground-based locations situated at different altitudes. The campaign was conducted from 12 March to 25 April 2000 in the vicinity of Svalbard. An overview of all the observation systems and the corresponding references is given in Table 2. Figure 2 presents example results for some ground-based measurements and demonstrates the variation of the available ground-based data sets. It shows daily mean values of the scattering coefficient at two different heights, the particle number concentration and a bar plot of one chosen chemical component. High concentrations of lead were found on two days (23 and 24 March 2000). However, in the time-series depicted below it can be seen that increased values of particle number concentrations occurred during two other periods as well.

Table 3 summarizes the measurement place and measurement time, as well as the simultaneous operating ground-based systems at Ny-Ålesund for the 17 days with flight activities during the ASTAR campaign,. Measurements of the vertical aerosol characteristics were carried out during clear sky conditions, in the height range from $250 \mathrm{~m}$ up to approximately $8 \mathrm{~km}$. Example results for 23 March and 26 March 2000 are shown in Fig. 3 to illustrate the vertical aerosol measurements. For 23 to 26 March 2000 the extinction measurements at $532 \mathrm{~nm}$ from the sun photometer took place at seven and eight different height levels, respectively. An aerosol layer was recorded on both days in the first $3 \mathrm{~km}$ but the measured extinction coefficients were about $60 \%$ less on 26 March than on 23 March 2000. Above this layer a rapid decrease of all values was observed on 26 March, whereas on 23 March the extinction coefficient remained higher until a height of $5 \mathrm{~km}$. A similar structure can be observed from the in situ measurements of the scattering and absorption coefficient profiles (see Fig. 3). Absorption and scattering coefficients as well as particle number concentration for each day were averaged before the HCA was applied according to the corresponding flight level of the airborne sun photometer measurements which differs from day to day. To account for the varying flight levels the mean layer height was included in the HCA.

As meteorology is an important factor in understanding the temporal and spatial variation of aerosols, local parameters of wind speed, temperature, relative humidity, pressure and global radiation were also included as daily averaged values in the HCA. Furthermore, large-scale meteorological transport systems may have considerable influence on the aerosol loading. Four-day back trajectories of air parcels starting at three different altitudes (1500, 3000 and $5000 \mathrm{~m})$ from Ny-Ålesund were analysed to trace the history of the sampled air masses. Four-day back trajectories were used because of concern that the cumulative errors in the parcel location beyond $4 \mathrm{~d}$ become very large. The backward trajectories were calculated at 12:00 UT for each day of the ASTAR campaign using the HYSPLIT model (HYbrid Single-Particle Lagrangian Integrated Trajectory). The HYSPLIT model is the newest version of a complete system for computing simple air parcel trajectories from complex dispersion and deposition simulations (Draxler and Rolph, 2003; Rolph 2003). Five sectors were chosen for this study. These sectors are 
Table 2. Overview of all the observation systems during the ASTAR 2000 campaign

\begin{tabular}{|c|c|c|}
\hline System & Measurement & References for system used \\
\hline \multicolumn{3}{|l|}{ Ground-based measurements: } \\
\hline \multicolumn{3}{|l|}{ Koldewey $\left(78^{\circ} 55^{\prime} N, 11^{\circ} 53^{\prime} E\right)$} \\
\hline Sun and star photometer & $\mathrm{AOD}$, phase function, RI & $\begin{array}{l}\text { Weller et al. (1998), } \\
\text { Herber et al. (2002) }\end{array}$ \\
\hline Aerosol Raman LIDAR & $\begin{array}{l}\text { Aerosol backscattering extinction coefficient } \\
\text { and depolarization factor at } 532 \text { and } 1064 \mathrm{~nm}\end{array}$ & $\begin{array}{l}\text { Ansmann et al. (1990), } \\
\text { Schumacher et al. (2001) }\end{array}$ \\
\hline Meteorology & Temp., RH, wind speed, wind direction & \\
\hline \multicolumn{3}{|l|}{ Rabben $\left(78^{\circ} 55^{\prime} N, 11^{\circ} 53^{\prime} E\right)$} \\
\hline Nephelometer TSI model 3563 & $\begin{array}{l}\text { Scattering coefficient at three wavelengths } \\
(450,550 \text { and } 700 \mathrm{~nm})\end{array}$ & Anderson et al. (1996) \\
\hline Optical particle counter & Particle number concentration & \\
\hline (MetOne model 227B and & MetOne 227B: $D=0.3 \mu \mathrm{m}$ and one of & \\
\hline RION model KC-01C) & $\begin{array}{l}0.5,1.0,3.0,5.0 \mu \mathrm{m} . \text { RION KC-01C: } \\
D=0.3,0.5,1.0,2.0,5.0 \mu \mathrm{m}\end{array}$ & \\
\hline Micropulse LIDAR & Backscatter ratio at $523 \mathrm{~nm}$ & $\begin{array}{l}\text { Spinhirne (1993), } \\
\text { Shiobara (2000) }\end{array}$ \\
\hline Sky scanning radiometer & AOD, size distribution, RI & Nakajima et al. (1996) \\
\hline Two-stage impactor & $\begin{array}{l}\text { High-volume sampler with a single-stage impactor } \\
\text { (cut-off diameter } 2 \mu \mathrm{m} \text { ): chemical aerosol } \\
\text { composition in dry and wet periods }\end{array}$ & $\begin{array}{l}\text { Kriews and Schrems (1998) } \\
\text { Luedke et al. (1999) }\end{array}$ \\
\hline \multicolumn{3}{|l|}{ Zeppelin Mountain $\left(78^{\circ} 54^{\prime} \mathrm{N}, 11^{\circ} 53^{\prime} \mathrm{E}\right)$} \\
\hline Nephelometer TSI 3563 & $\begin{array}{l}\text { Scattering coefficient at three wavelengths } \\
(450,550 \text { and } 700 \mathrm{~nm})\end{array}$ & Anderson et al. (1996) \\
\hline DMPS & $\begin{array}{l}\text { Particle number concentration } \\
\text { Size range between } 0.025 \text { and } 0.5 \mu \mathrm{m}\end{array}$ & $\begin{array}{l}\text { Knutson and Whitby (1975) } \\
\text { Jokinen and Mäkelä (1997) } \\
\text { Ström et al. (2003) }\end{array}$ \\
\hline \multicolumn{3}{|l|}{ Aircraft measurements: } \\
\hline Sun photometer & $\mathrm{AOD}$, phase function, RI & $\begin{array}{l}\text { Leiterer et al. (1997), } \\
\text { Nagel et al. (1998) }\end{array}$ \\
\hline Nephelometer: Radiance Res. M903 & Scattering coefficient at $530 \mathrm{~nm}$ & \\
\hline Optical particle counter & Particle number concentration & \\
\hline (MetOne model $237 \mathrm{H}$ and & $237 \mathrm{H}$ size range: $D=0.1,0.2,0.3,0.5,1 \mu \mathrm{m}$ & \\
\hline 237B) & 237B size range: $D=0.3,0.5,1,5 \mu \mathrm{m}$ & \\
\hline $\begin{array}{l}\text { Particle soot absorption } \\
\text { photometer (Radiance Research) }\end{array}$ & Absorption coefficient at $565 \mathrm{~nm}$ & Bond et al., 1999 \\
\hline Filter sampling & Ionic and metal constituents & \\
\hline One-stage aerosol impactor & $\begin{array}{l}\text { Individual particle analysis, mixing state and } \\
\text { morphology observation, cut-off diameter } \\
\text { c. } 0.2 \mu \mathrm{m} \text { at ground level }\end{array}$ & $\begin{array}{l}\text { Hara et al. (2002) } \\
\text { Hara et al. (2003) }\end{array}$ \\
\hline Basic sensor systems & Meteorological data & \\
\hline \multicolumn{3}{|l|}{ Satellite measurements } \\
\hline $\begin{array}{l}\text { SAGE II (Stratospheric Aerosol } \\
\text { and Gas Experiment II) }\end{array}$ & Aerosol extinction coefficient & $\begin{array}{l}\text { Wang et al. (1999), } \\
\text { Thomason et al. (2003) }\end{array}$ \\
\hline
\end{tabular}

Abbreviations: AOD, aerosol optical depth; RI, refractive index; DMPS, differential mobility particle sizer.

in accordance with the trajectory analysis for Ny-Ålesund performed by Eneroth et al. (2003). Sector 1 was defined between $-15^{\circ}$ and $45^{\circ}$ to present air mass transport from Europe, sector 2 between $45^{\circ}$ and $150^{\circ}$ to present air mass transport from
Russia and Siberia, sector 3 for $150^{\circ}$ to $-135^{\circ}$ to present air mass transport over the North Pole, sector 4 between $-135^{\circ}$ and $-60^{\circ}$ to present air mass transport from Alaska and sector 5 between $-60^{\circ}$ and $-15^{\circ}$ to cover air mass transport over Greenland. Prior 


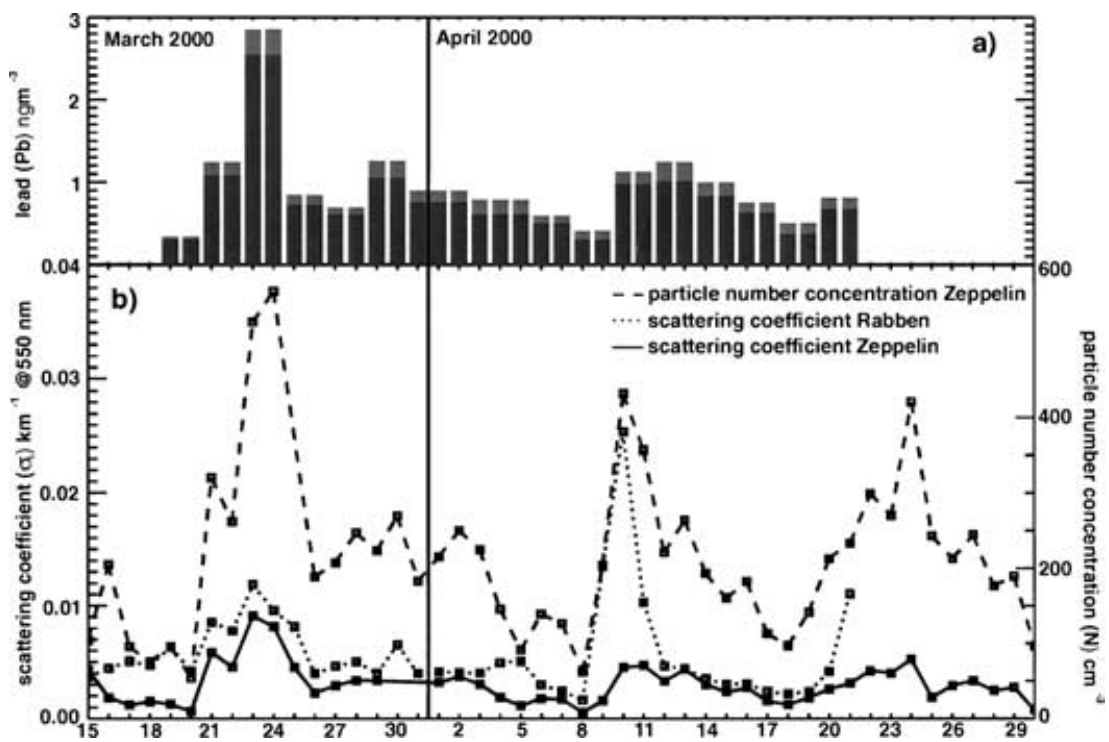

Fig 2. Daily mean values of selected aerosol parameters for the ASTAR campaign. (a) Lead concentration at Rabben station (dark bars for cut-off of $\mathrm{dp}<2 \mu \mathrm{m}$ and light bars for $\mathrm{dp}>2 \mu \mathrm{m}$ ). (b) Daily mean value of the particle number concentration and scattering coefficient at $550 \mathrm{~nm}$ from Zeppelin Mountain as well as the scattering coefficient at $550 \mathrm{~nm}$ from Rabben station (for details on measurement time and measurement system see Table 1).

Table 3. (a) Airborne activities during ASTAR 2000

\begin{tabular}{|c|c|c|c|c|c|c|c|}
\hline \multirow{2}{*}{$\begin{array}{l}\text { Flight } \\
\text { no }\end{array}$} & \multirow{2}{*}{$\begin{array}{c}\text { Date } \\
\text { in } 2000 \\
15 \text { March }\end{array}$} & \multicolumn{2}{|c|}{ Location } & \multirow{2}{*}{$\begin{array}{c}\text { Systems }^{\mathrm{a}} \\
\mathrm{x}\end{array}$} & \multirow{2}{*}{$\begin{array}{c}\begin{array}{c}\text { Start time } \\
\text { (hh:mm) }\end{array} \\
10: 07\end{array}$} & \multirow{2}{*}{$\begin{array}{c}\begin{array}{c}\text { Duration } \\
\text { (hh:mm) }\end{array} \\
03: 39\end{array}$} & \multirow{2}{*}{$\begin{array}{c}\text { Height (m) for 1st } \\
\text { AOD level } \\
86\end{array}$} \\
\hline & & Near Ny-Ålesund & $79^{\circ} \mathrm{N} / 8^{\circ} \mathrm{E}$ & & & & \\
\hline 2 & 23 March & Ny-Ålesund & $79^{\circ} \mathrm{N} / 11^{\circ} \mathrm{E}$ & $\times$ & $10: 30$ & 03:01 & 55 \\
\hline 3 & 24 March & Longyearbyen & $78^{\circ} \mathrm{N} / 12^{\circ} \mathrm{E}$ & $\times$ & $08: 40$ & $04: 41$ & 68 \\
\hline 4 & 25 March & Ny-Ålesund & $78^{\circ} \mathrm{N} / 12^{\circ} \mathrm{E}$ & $x^{b}$ & $07: 43$ & $03: 32$ & 76 \\
\hline 5 & 26 March & E of Svalbard & $79^{\circ} \mathrm{N} / 24^{\circ} \mathrm{E}$ & $x^{b, c}$ & 09:29 & $04: 58$ & 92 \\
\hline 6 & 28 March & Ny-Ålesund & $79^{\circ} \mathrm{N} / 24^{\circ} \mathrm{E}$ & $x^{c}$ & 08:42 & $04: 21$ & 59 \\
\hline 7 & 30 March & E of Svalbard & $76^{\circ} \mathrm{N} / 18^{\circ} \mathrm{E}$ & $x^{c}$ & 11.22 & $04: 58$ & 378 \\
\hline 8 & 1 April & Longyearbyen & $79^{\circ} \mathrm{N} / 15^{\circ} \mathrm{E}$ & $x^{c}$ & 09:07 & $03: 33$ & 488 \\
\hline 9 & 2 April & S of Svalbard & $77^{\circ} \mathrm{N} / 13^{\circ} \mathrm{E}$ & $x^{c}$ & $12: 27$ & 03:43 & 62 \\
\hline 10 & 4 April & SE of Svalbard & $76^{\circ} \mathrm{N} / 20^{\circ} \mathrm{E}$ & $\times$ & 13:02 & 04:07 & 60 \\
\hline 11 & 7 April & Longyearbyen & $79^{\circ} \mathrm{N} / 15^{\circ} \mathrm{E}$ & $x$ & 13.13 & $04: 32$ & 82 \\
\hline 12 & 12 April & Ny-Ålesund & $79^{\circ} \mathrm{N} / 12^{\circ} \mathrm{E}$ & $\times$ & $14: 15$ & $03: 28$ & 64 \\
\hline 13 & 13 April & Near Ny-Ålesund & $79^{\circ} \mathrm{N} / 11^{\circ} \mathrm{E}$ & $x$ & $14: 26$ & $04: 56$ & 486 \\
\hline 14 & 14 April & Longyearbyen & $78^{\circ} \mathrm{N} / 15^{\circ} \mathrm{E}$ & $x$ & $14: 29$ & 04:59 & 3360 \\
\hline 15 & 16 April & Ny-Ålesund & $79^{\circ} \mathrm{N} / 11^{\circ} \mathrm{E}$ & $x$ & $14: 55$ & $03: 26$ & 68 \\
\hline 16 & 17 April & $S$ of Svalbard & $74^{\circ} \mathrm{N} / 11^{\circ} \mathrm{E}$ & $x$ & $15: 50$ & 04:49 & 1426 \\
\hline 17 & 19 April & $\mathrm{S}$ of Svalbard & $74^{\circ} \mathrm{N} / 8^{\circ} \mathrm{E}$ & $x$ & $16: 34$ & $04: 37$ & 1428 \\
\hline
\end{tabular}

${ }^{\mathrm{a}} \times$ means all instruments working (photometer, integrating nephelometer, particle soot/absorption photometer, optical particle counter, impactor, filter sampling and meteorology).

${ }^{\mathrm{b}}$ Without filter sampling.

${ }^{\mathrm{c}}$ No impactor measurements.

to the HCA each trajectory was grouped twice according to its start sector and its sector of longest residence time. These two variables were incorporated into the HCA to take into account the air mass history.

\section{Data analysis method}

Hierarchical cluster analysis (HCA) was applied as the data analysis method. This method is beneficial as it allows a group classification and provides the opportunity to calculate groupdefining values. Cluster analysis (CA) is an exploratory data analysis tool for solving classification problems. Its object is to sort cases into groups, or clusters, so that the degree of association is strong between members of the same cluster and weak between members of different clusters. Searching the data for a structure of inherent groupings is an important exploratory technique in air quality modelling. As an exploratory technique with graphical output, cluster analysis does not require many of the 
Table 3. (b) Related ground-based activities during ASTAR 2000. Key to column headings is as follows: A, Aerosol Raman LIDAR; B, Photometer; C, Meteorological data; D, Micropulse LIDAR; E, sky radiometer; F, integrating nephelometer; $\mathrm{G}, \mathrm{OPC} ; \mathrm{H}$, two-stage impactor; I, differential mobility particle sizer (DMPS); J, integrating nephelometer.

\begin{tabular}{|c|c|c|c|c|c|c|c|c|c|c|c|}
\hline \multirow{2}{*}{$\begin{array}{l}\text { Flight } \\
\text { no }\end{array}$} & \multirow{2}{*}{$\begin{array}{c}\text { Date } \\
\text { in } 2000\end{array}$} & \multicolumn{3}{|c|}{ Koldewey } & \multicolumn{5}{|c|}{ Rabben } & \multicolumn{2}{|c|}{ Zeppelin } \\
\hline & & A & B & $\mathrm{C}^{\mathrm{d}}$ & D & $\mathrm{E}$ & $\mathrm{F}$ & G & $\mathrm{H}$ & $\mathrm{I}$ & $\mathrm{J}$ \\
\hline 1 & 15 March & $\times$ & $x^{e}$ & $x^{f}$ & $\times$ & $\times$ & - & - & - & $\times$ & $\times$ \\
\hline 2 & 23 March & $x$ & $\times$ & $x^{f}$ & $\times$ & $\times$ & $\times$ & $x^{g}$ & $\times$ & $\times$ & $x$ \\
\hline 3 & 24 March & $\times$ & $x^{e}$ & $x$ & $\times$ & $x$ & $\times$ & $x^{g}$ & $x$ & $\times$ & $x$ \\
\hline 4 & 25 March & $\times$ & $x^{e}$ & $\times$ & $\times$ & $\times$ & $\times$ & $x^{g}$ & $\times$ & - & $x$ \\
\hline 5 & 26 March & - & - & $x^{f}$ & - & - & $\times$ & $x^{g}$ & $\times$ & $x$ & $x$ \\
\hline 6 & $28 \mathrm{March}$ & $x$ & $\times$ & $x^{f}$ & $\times$ & $\times$ & $\times$ & $x^{g}$ & $\times$ & $x$ & $\times$ \\
\hline 7 & 30 March & $x$ & - & $\times$ & $\times$ & $\times$ & $\times$ & $x^{g}$ & $\times$ & $x$ & $x$ \\
\hline 8 & 1 April & $\times$ & $\times$ & $x$ & $\times$ & $\times$ & $\times$ & $x^{g}$ & $\times$ & $x$ & $\times$ \\
\hline 9 & 2 April & $\times$ & - & $x^{f}$ & $\times$ & $\times$ & $\times$ & $x^{g}$ & $\times$ & $\times$ & $\times$ \\
\hline 10 & 4 April & - & - & $x^{f}$ & - & - & $\times$ & $x^{h}$ & $\times$ & $x$ & $x$ \\
\hline 11 & 7 April & $\times$ & - & $\times$ & $\times$ & $\times$ & $\times$ & $x^{h}$ & $\times$ & $\times$ & $\times$ \\
\hline 12 & 12 April & $\times$ & $\times$ & $x^{f}$ & $\times$ & $\times$ & $\times$ & $x^{h}$ & $x$ & $\times$ & $x$ \\
\hline 13 & 13 April & $\times$ & $\times$ & $x$ & $x$ & $x$ & $x$ & $x^{h}$ & $\times$ & $\times$ & $\times$ \\
\hline 14 & 14 April & $\times$ & - & $\times$ & $\times$ & $\times$ & $\times$ & $x^{h}$ & $\times$ & $\times$ & $\times$ \\
\hline 15 & 16 April & $x$ & - & $\times$ & $\times$ & $\times$ & $\times$ & $x^{h}$ & $\times$ & $\times$ & $\times$ \\
\hline 16 & 17 April & $x$ & - & $x^{f}$ & $\times$ & $x$ & $\times$ & $x^{h}$ & $\times$ & $x$ & $\times$ \\
\hline 17 & 19 April & $\times$ & $\times$ & $x^{f}$ & $\times$ & $\times$ & $\times$ & $x^{h}$ & $x$ & $\times$ & $\times$ \\
\hline
\end{tabular}

${ }^{\mathrm{d}}$ Radio sounding and BRSN (baseline surface radiation network).

${ }^{\mathrm{e}}$ Also star photometer.

${ }^{\mathrm{f}}$ Additional ozone sounding.

${ }^{\mathrm{g}}$ MetOne OPC.

${ }^{\mathrm{h}} \mathrm{RION}$ OPC.

assumptions that other statistical methods do, except that the data are heterogeneous. Therefore, this method is often used in environmental science (Ho et al., 2002; de Miranda et al., 2002; Eneroth et al., 2003). Cluster analysis techniques are hierarchical or non-hierarchical. The hierarchical method of cluster analysis has the advantage of not demanding any prior knowledge about the number of clusters, whereas the non-hierarchical method does. However, with an increasing number of data points, the calculation for the hierarchical method increases disproportionately. HCA was used to perform this study.

Ward's clustering procedure was applied in this paper following a review by Sharma (1996) which suggests that Ward's clustering method is superior because it yields a larger proportion of correctly classified observations than most other methods. In general, this method is regarded as very efficient. A problem with Ward's method could be its tendency to produce tight clusters-it joins the outlier with another single object, rather than grouping existing clusters into larger clusters. For this study, the squared Euclidean distance was used as a distance measure. This is one of the most commonly adopted measures (e.g. Fovell and Fovell, 1993). Furthermore, complete linkage clustering was applied to minimize the maximum intercluster distance at each stage (e.g.
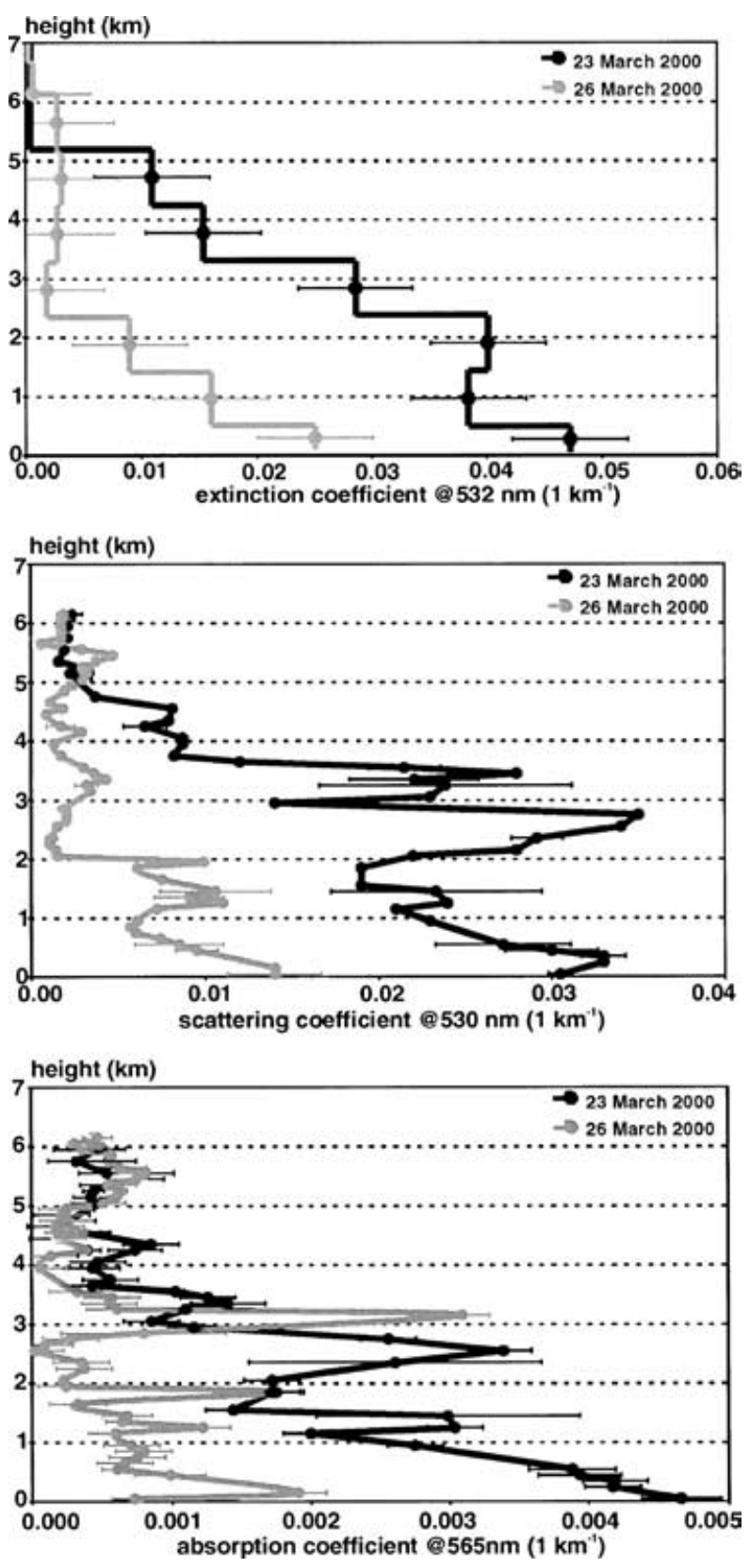

Fig 3. Vertical profiles of the extinction, scattering and absorption coefficient for 23 and 26 March 2000. For the extinction coefficient the value of the mean measured layer is marked and the vertical line represents the layer thickness. The continuous measurements of scattering and absorption coefficient were averaged over a height of $100 \mathrm{~m}$ (error bars represent measurement errors).

Smolinski et al., 2002). Prior to the performed clustering a data transformation was necessary to ensure that each variable in the database (see Section 2 for details) is given appropriate weight in the analysis and contributes equally to the variance in the analysis. To standardize each variable $z$-scores were calculated, which have a mean of zero and a standard deviation of 1 . A difficult 


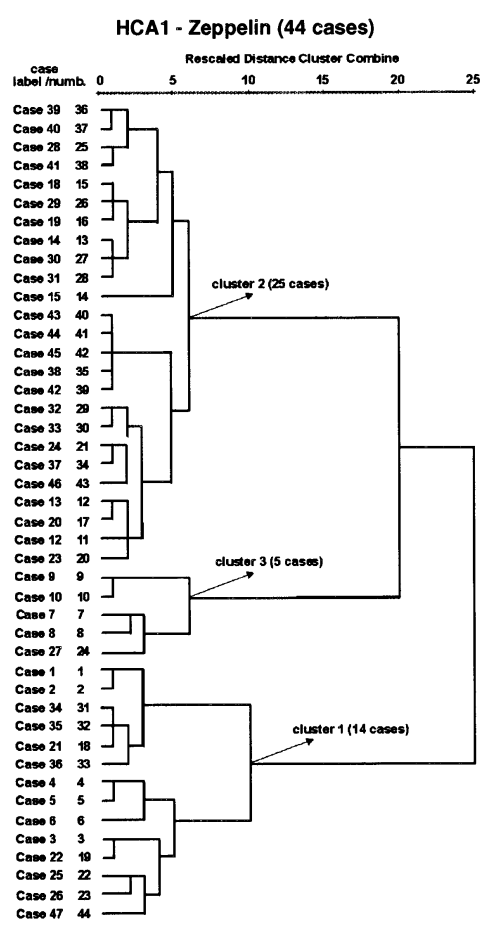

HCA3 - Zeppelin/Rabben (35 cases)

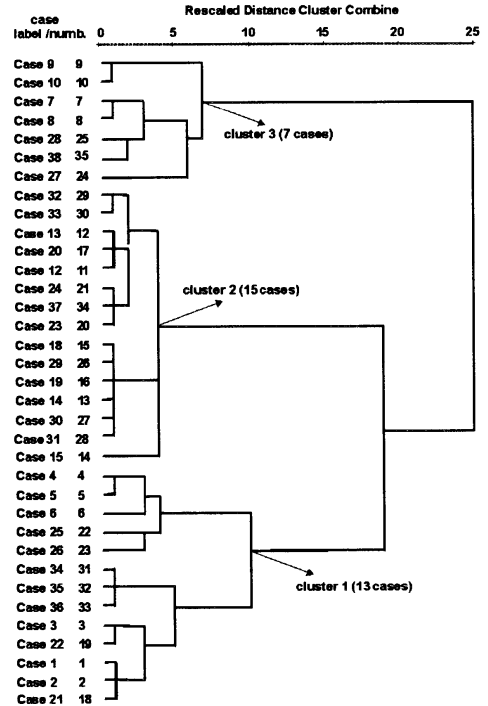

HCA2 - Rabben (37 cases)

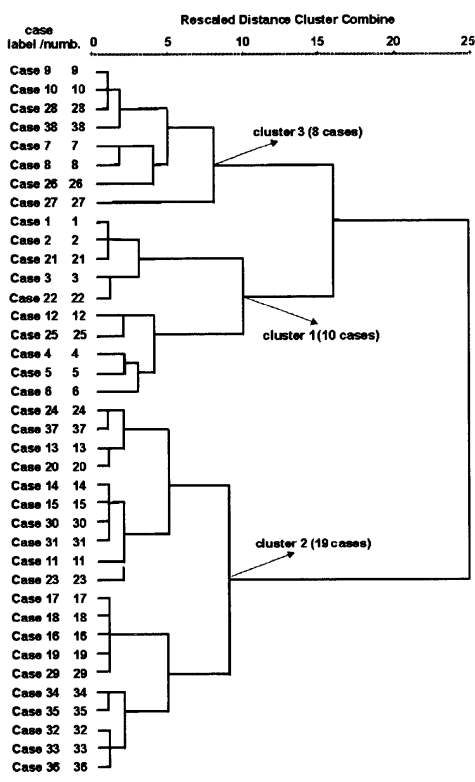

HCA4 - Zeppelin/Rabben and chemical species (31 cases)

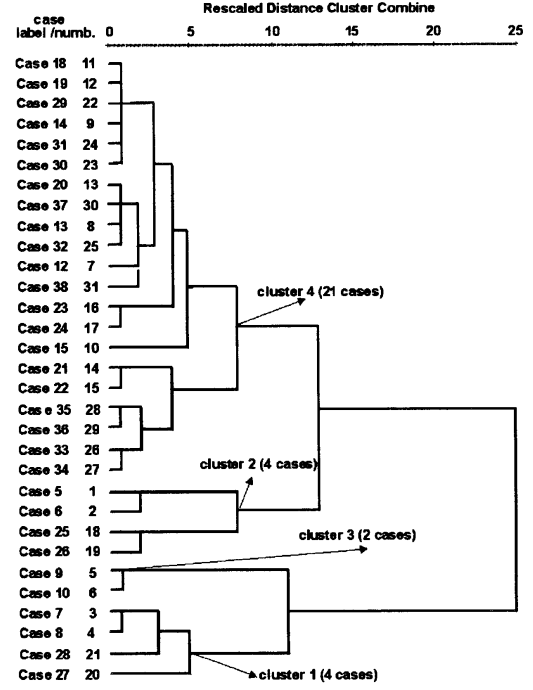

Fig 4. Depicted cluster analysis results according to Ward (Sharma, 1996) of the four performed HCA for the ground-based data set as dendrograms. Parameters included in each performed HCA are listed in Table 1. The obtained clusters are marked. Corresponding statistical values are listed in Tables 4, 5 and 6 . problem facing the user of HCA in practice is the objective assessment of the stability and validity of the clusters found by the numerical technique used. The problem of determining the "true" number of clusters has been called the fundamental problem of cluster validity. The result of the HCA is analysed graphically by a tree that shows at which distance the cluster merges (a dendrogram). When the data contain a clear "structure" in terms of objects that are similar to each other, then this structure will often be reflected in the dendrogram as distinct branches. We tried to identify which number of groups would be the best for our purpose, using a rescaled distance of cluster combination (e.g. Smolinski et al., 2002). Finally, it should be noted that even though CA is described as an objective method, the selection of the algorithm, the specification of the distance measure and the number of clusters are subjective (e.g. Stohl, 1998).

The discriminant analysis with a discriminant projection and the non-parametric Kruskal-Wallis test were applied to test for and validate statistical differences among the classified groups (Conover, 1971; Rosner, 1995; Tabanick and Fidell, 1996). Discriminant analysis is a technique for classifying a set of observations into pre-defined classes. The purpose is to determine the class of an observation based on a set of variables known as 
Table 4. Calculated mean statistical values for the clusters obtained by the performed HCA (ground-based without chemical components). Corresponding parameters used for the different HCA are listed in Table 1

\begin{tabular}{|c|c|c|c|c|c|c|c|c|c|c|c|}
\hline & \multirow{2}{*}{$\begin{array}{c}\text { HCA } \\
\text { no }^{\mathrm{a}}\end{array}$} & \multicolumn{3}{|c|}{ Cluster 1} & \multicolumn{3}{|c|}{ Cluster 2} & \multicolumn{3}{|c|}{ Cluster 3} & \multirow[b]{2}{*}{ Sig. ${ }^{\text {b }}$} \\
\hline & & Median & Mean & $S D$ & Median & Mean & $S D$ & Median & Mean & $S D$ & \\
\hline \multicolumn{12}{|c|}{ Zeppelin } \\
\hline \multicolumn{12}{|c|}{ Parameters of the lognormal distribution } \\
\hline \multirow[t]{3}{*}{$\mathrm{n} 1\left(\mathrm{~cm}^{-3}\right)$} & HCA1 & 21 & 25 & 13 & 20 & 22 & 9 & 56 & 63 & 24 & 0.003 \\
\hline & $\mathrm{HCA} 2$ & 17 & 21 & 13 & 20 & 20 & 8 & 50 & 50 & 26 & 0.006 \\
\hline & HCA3 & 20 & 25 & 14 & 20 & 19 & 7 & 49 & 50 & 29 & 0.014 \\
\hline \multirow[t]{3}{*}{ s1 } & HCA1 & 1.4 & 1.4 & 0.1 & 1.3 & 1.3 & 0.0 & 1.3 & 1.3 & 0.1 & 0.001 \\
\hline & HCA2 & 1.3 & 1.3 & 0.0 & 1.2 & 1.3 & 0.1 & 1.3 & 1.3 & 0.1 & 0.056 \\
\hline & HCA3 & 1.4 & 1.4 & 0.1 & 1.2 & 1.3 & 0.0 & 1.3 & 1.3 & 0.1 & 0.000 \\
\hline \multirow[t]{3}{*}{$\mathrm{dp} 1(\mu \mathrm{m})$} & HCA1 & 0.04 & 0.04 & 0.00 & 0.05 & 0.05 & 0.00 & 0.05 & 0.05 & 0.00 & 0.000 \\
\hline & $\mathrm{HCA} 2$ & 0.05 & 0.04 & 0.01 & 0.05 & 0.05 & 0.00 & 0.05 & 0.05 & 0.00 & 0.019 \\
\hline & HCA3 & 0.04 & 0.04 & 0.0 & 0.05 & 0.05 & 0.00 & 0.05 & 0.05 & 0.00 & 0.000 \\
\hline \multirow[t]{3}{*}{$\mathrm{n} 2\left(\mathrm{~cm}^{-3}\right)$} & HCA1 & 34 & 37 & 21 & 80 & 79 & 31 & 206 & 259 & 123 & 0.000 \\
\hline & HCA2 & 39 & 37 & 14 & 71 & 64 & 34 & 152 & 200 & 123 & 0.000 \\
\hline & $\mathrm{HCA} 3$ & 33 & 38 & 21 & 71 & 67 & 30 & 160 & 214 & 126 & 0.000 \\
\hline \multirow[t]{3}{*}{$\mathrm{s} 2$} & HCA1 & 1.3 & 1.4 & 0.1 & 1.3 & 1.3 & 0.0 & 1.4 & 1.3 & 0.0 & 0.000 \\
\hline & $\mathrm{HCA} 2$ & 1.3 & 1.4 & 0.1 & 1.3 & 1.3 & 0.0 & 1.3 & 1.3 & 0.1 & 0.002 \\
\hline & HCA3 & 1.3 & 1.4 & 0.1 & 1.3 & 1.3 & 0.0 & 1.33 & 1.33 & .05 & 0.000 \\
\hline \multirow[t]{3}{*}{$\mathrm{dp} 2(\mu \mathrm{m})$} & HCA1 & 0.09 & 0.10 & 0.01 & 0.12 & 0.12 & 0.01 & 0.13 & 0.13 & 0.01 & 0.000 \\
\hline & HCA2 & 0.10 & 0.10 & .02 & 0.11 & 0.11 & 0.01 & 0.12 & 0.12 & 0.02 & 0.077 \\
\hline & HCA3 & 0.09 & 0.10 & 0.0 & 0.12 & 0.11 & 0.01 & 0.12 & 0.12 & 0.01 & 0.001 \\
\hline \multirow[t]{3}{*}{$\mathrm{n} 3\left(\mathrm{~cm}^{-3}\right)$} & HCA1 & 46 & 56 & 33 & 121 & 134 & 43 & 96 & 97 & 19 & 0.000 \\
\hline & HCA2 & 42 & 63 & 50 & 117 & 115 & 29 & 102 & 115 & 57 & 0.020 \\
\hline & HCA3 & 47 & 58 & 34 & 121 & 126 & 24 & 108 & 121 & 59 & 0.000 \\
\hline \multirow[t]{3}{*}{ s3 } & HCA1 & 1.4 & 1.4 & 0.1 & 1.4 & 1.4 & 0.1 & 1.4 & 1.3 & 0.0 & 0.003 \\
\hline & HCA2 & 1.4 & 1.4 & 0.1 & 1.4 & 1.4 & 0.1 & 1.4 & 1.4 & 0.1 & 0.065 \\
\hline & HCA3 & 1.4 & 1.4 & 0.1 & 1.4 & 1.5 & 0.1 & 1.4 & 1.4 & 0.1 & 0.017 \\
\hline \multirow[t]{3}{*}{$\mathrm{dp} 3(\mu \mathrm{m})$} & HCA1 & 0.18 & 0.18 & 0.02 & 0.18 & 0.18 & 0.02 & 0.22 & 0.23 & 0.02 & 0.001 \\
\hline & HCA2 & 0.19 & 0.19 & 0.02 & 0.17 & 0.17 & 0.01 & 0.21 & 0.21 & 0.03 & 0.003 \\
\hline & HCA3 & 0.18 & 0.18 & 0.00 & 0.17 & 0.17 & 0.01 & 0.22 & 0.22 & 0.03 & 0.002 \\
\hline \multicolumn{12}{|c|}{ Partic. number conc. $\left(\mathrm{cm}^{-3}\right)$} \\
\hline & HCA1 & 97 & 113 & 46 & 221 & 228 & 63 & 432 & 421 & 130 & 0.000 \\
\hline & HCA2 & 95 & 111 & 51 & 208 & 193 & 51 & 338 & 362 & 134 & 0.000 \\
\hline & HCA3 & 97 & 114 & 48 & 213 & 204 & 39 & 357 & 385 & 128 & 0.000 \\
\hline \multicolumn{12}{|c|}{ Scattering coefficient $550 \mathrm{~nm}\left(\mathrm{~km}^{-1}\right)$} \\
\hline & HCA1 & 0.0014 & 0.0015 & 0.0008 & 0.0030 & 0.0031 & 0.0009 & 0.0059 & 0.0064 & 0.0021 & 0.000 \\
\hline & HCA2 & 0.0014 & 0.0016 & 0.0009 & 0.0030 & 0.0028 & 0.0009 & 0.0046 & 0.0052 & 0.0025 & 0.000 \\
\hline & HCA3 & 0.0015 & 0.0015 & 0.0008 & 0.0030 & 0.0029 & 0.0007 & 0.0047 & 0.0057 & 0.0022 & 0.000 \\
\hline \multicolumn{12}{|c|}{ Colour ratio $450 \mathrm{~nm} / 700 \mathrm{~nm}$} \\
\hline & HCA1 & 2.8 & 2.8 & 0.3 & 2.9 & 2.9 & 0.2 & 2.7 & 2.7 & 0.1 & 0.075 \\
\hline & $\mathrm{HCA} 2$ & 2.8 & 2.8 & 0.3 & 2.8 & 2.9 & 0.1 & 2.8 & 2.8 & 0.1 & 0.617 \\
\hline & HCA3 & 2.8 & 2.8 & 0.3 & 2.8 & 2.9 & 0.1 & 2.7 & 2.8 & 0.2 & 0.477 \\
\hline
\end{tabular}

predictors or input variables. The model is built based on a set of observations for which the classes are known. This set of observations is sometimes referred to as the training set. Based on the training set, the technique constructs a set of linear functions of the predictors, known as discriminant functions. These discriminant functions are used to predict the class of a new observation with an unknown class (Conover, 1971; Rosner, 1995; Tabanick and Fidell, 1996).

\section{Results and discussion}

\subsection{Ground-based time series during ASTAR}

For the ground-based measurements the HCA consisted of four different analyses. Each data set at different height levels was analysed separately (HCA1 and HCA2) and combined (HCA3). Finally, the analysis was performed by integrating the 
Table 4. (Continued)

\begin{tabular}{|c|c|c|c|c|c|c|c|c|c|c|}
\hline \multirow{2}{*}{$\begin{array}{c}\text { HCA } \\
\text { no }^{\mathrm{a}}\end{array}$} & \multicolumn{3}{|c|}{ Cluster 1} & \multicolumn{3}{|c|}{ Cluster 2} & \multicolumn{3}{|c|}{ Cluster 3} & \multirow[b]{2}{*}{ Sig. ${ }^{b}$} \\
\hline & Median & Mean & $S D$ & Median & Mean & $S D$ & Median & Mean & $S D$ & \\
\hline \multicolumn{11}{|l|}{ Rabben } \\
\hline \multicolumn{11}{|c|}{ Partic. number conc. $\left(\mathrm{cm}^{-3}\right)$} \\
\hline HCA1 & 6 & 8 & 6 & 11 & 12 & 5 & 26 & 28 & 9 & 0.001 \\
\hline HCA2 & 7 & 7 & 2 & 11 & 11 & 5 & 25 & 26 & 8 & 0.000 \\
\hline HCA3 & 6 & 8 & 6 & 11 & 10 & 2 & 23 & 26 & 8 & 0.000 \\
\hline \multicolumn{11}{|c|}{ Scattering coefficient $550 \mathrm{~nm}\left(\mathrm{~km}^{-1}\right)$} \\
\hline HCA1 & 0.0054 & 0.0058 & 0.0035 & 0.0065 & 0.0069 & 0.0029 & 0.0147 & 0.0172 & 0.0077 & 0.000 \\
\hline HCA2 & 0.0058 & 0.0055 & 0.0014 & 0.0063 & 0.0062 & 0.0023 & 0.0145 & 0.0163 & 0.0060 & 0.000 \\
\hline HCA3 & 0.0054 & 0.0058 & 0.0035 & 0.0064 & 0.0060 & 0.0011 & 0.0144 & 0.0163 & 0.0065 & 0.000 \\
\hline \multicolumn{11}{|c|}{ Colour ratio $450 \mathrm{~nm} / 700 \mathrm{~nm}$} \\
\hline HCA1 & 1.6 & 1.6 & 0.4 & 2.2 & 2.1 & 0.2 & 1.9 & 1.9 & 0.3 & 0.001 \\
\hline HCA2 & 1.5 & 1.6 & 0.3 & 2.2 & 2.2 & 0.1 & 1.8 & 1.8 & 0.3 & 0.000 \\
\hline HCA3 & 1.6 & 1.7 & 0.4 & 2.2 & 2.2 & 0.1 & 1.8 & 1.8 & 0.3 & 0.000 \\
\hline
\end{tabular}

aParameters used for the HCA are listed in Table 1. Analysis was performed without chemical components. HCA1 = Zeppelin Mountain: cluster $1(n=14)$; cluster $2(n=25)$; cluster $3(n=5)$. HCA2 = Rabben: cluster $1(n=10)$; cluster $2(n=19)$; cluster $3(n=8)$. HCA3= Rabben and Zeppelin: cluster $1(n=13)$; cluster $2(n=15)$; cluster $3(n=7)$.

${ }^{\mathrm{b}}$ Bold entries show when the difference between the clusters is not significant based on the Kruskal-Wallis test.

chemical species, as mentioned in Table 1 (HCA4). The results of the first three HCA performed are graphically depicted as dendrograms in Fig. 4. The length of the edges connecting nodes gives information about the degree of dissimilarity between the clusters. As is often used for visualizing CA cluster results, the horizontal axis denotes the rescaled distance of cluster combination. Thus, for each node in the graph (where a new cluster is formed) the distance criterion at which the respective elements were linked together into a new single cluster can be read off. The further to the right, the more dissimilar the clusters are. As seen in Fig. 4, the clustering starts to become less active near distances around 10 for performance of HCA1, HCA2 and HCA3. Based on the dendrograms, we draw the conclusion that for each of these HCAs three clusters represents the variation during the ASTAR period. Each cluster is assigned an identification number (cluster 1 to 3). Discriminant projections as an output of the applied discriminant analysis were also plotted to get an impression of the separateness of the resulting clusters. They showed a clear separation (not depicted here). As the analysed data are not normally distributed, a Kruskal-Wallis test was performed to compare the statistical significance of the grouping. At the $\alpha=0.05$ level of significance, there exists enough evidence to conclude that for almost all parameters there is a statistical difference among the three clusters determined with HCA1, HCA2 and HCA3 (see Tables 4 and 5). The cluster mean represents the average characteristics in a cluster including the air mass history within a four-day transport time to Ny-Ålesund. The corresponding statistical values for each cluster are summarized in Tables 4 and 5 . The variation of the data set can thus be expressed by these mean cluster values. Within the variance, similar clusterdefining values can be obtained among the three HCAs. It can be seen from Table 5 that the trajectory information of the obtained clusters is not statistically significant. This might be attributed to the small number of cases. There is nevertheless a tendency to find specific air masses within the obtained clusters. Cluster 3 shows the highest particle number concentration and scattering coefficient connected with low mean pressure and low mean global radiation, which suggest low-pressure influence. Indeed, low-pressure systems are reported for the days belonging to cluster 3. For example, on 22 March 2000 a distinctive low-pressure system southeast of Svalbard was established with a predominantly northeast wind-flow pattern, which remained stable and persistent until 25 March 2000. This whole period is classified in cluster 3 . During the time of the highest aerosol loading, the low moved and expanded southeast. Cluster 2 is characterized by the lowest mean temperature and the highest mean pressure as well as mean global radiation, indicating that high-pressure systems form this group. The differences in the mean scattering coefficient for each group between Rabben and Zeppelin Mountain are remarkable; they are due to the decrease of aerosol concentration with altitude. They show the largest difference for cluster 1 (almost a factor of 4), whereas the differences are around a factor of 2 and 3 for the other two clusters. Cluster 2 represents transport from the North and the Canadian Arctic, whereas cluster 3 comprises trajectories originating from the Eurasian continent (see Table 5). In the next step the ground-based time-series were analysed, including the chemical components.

The chemical species used for HCA4 represent the chemical signature of a variety of source types. $\mathrm{Cd}, \mathrm{Pb}, \mathrm{Ti}, \mathrm{Ni}, \mathrm{Co}, \mathrm{Cu}, \mathrm{Zn}$, $\mathrm{S}$ are considered to be of anthropogenic origin (e.g. Xie et al., 1999). Mn, Al and $\mathrm{Fe}$ are known to be the major constituents of soil, which suggests there is wind-blown soil dust in the Arctic 
Table 5. Calculated mean statistical values and dominating trajectory sectors for the clusters obtained by the performed HCA (ground-based without chemical components). Corresponding parameters used for the different HCA are listed in Table 1

\begin{tabular}{|c|c|c|c|c|c|c|c|c|c|c|c|}
\hline & \multirow{2}{*}{$\begin{array}{c}\mathrm{HCA} \\
\mathrm{no}^{\mathrm{a}}\end{array}$} & \multicolumn{3}{|c|}{ Cluster 1} & \multicolumn{3}{|c|}{ Cluster 2} & \multicolumn{4}{|c|}{ Cluster 3} \\
\hline & & Median & Mean & $S D$ & Median & Mean & $S D$ & Median & Mean & $S D$ & Sig. ${ }^{\text {b }}$ \\
\hline \multicolumn{12}{|c|}{ Meteorology } \\
\hline & HCA1 & -5 & -5 & 3 & -13 & -14 & 3 & -11 & -9 & 4 & 0.000 \\
\hline & $\mathrm{HCA} 2$ & -5 & -5 & 3 & -15 & -15 & 3 & -11 & -9 & 4 & 0.000 \\
\hline & HCA3 & -5 & -6 & 3 & -15 & -15 & 3 & -12 & -10 & 4 & 0.000 \\
\hline & HCA1 & 76 & 74 & 12 & 65 & 62 & 10 & 64 & 64 & 5 & 0.011 \\
\hline \multirow[t]{2}{*}{ RH (\%) } & HCA2 & 76 & 77 & 7 & 55 & 57 & 10 & 64 & 68 & 9 & 0.000 \\
\hline & HCA3 & 76 & 73 & 12 & 62 & 58 & 11 & 64 & 66 & 6 & 0.008 \\
\hline \multirow[t]{3}{*}{ Pressure (hPa) } & HCA1 & 1012 & 999 & 17 & 1014 & 1014 & 6 & 998 & 997 & 11 & 0.002 \\
\hline & HCA2 & 998 & 995 & 14 & 1014 & 1014 & 5 & 1001 & 997 & 14 & 0.000 \\
\hline & HCA3 & 1001 & 996 & 16 & 1013 & 1013 & 6 & 1004 & 1001 & 11 & 0.002 \\
\hline \multicolumn{12}{|l|}{$\mathrm{GR}\left(\mathrm{W} \mathrm{m}^{-2}\right)$} \\
\hline & HCA1 & 52 & 71 & 58 & 137 & 130 & 49 & 51 & 55 & 19 & 0.015 \\
\hline & HCA2 & 28 & 34 & 15 & 102 & 113 & 45 & 69 & 77 & 37 & 0.000 \\
\hline & HCA3 & 42 & 67 & 58 & 95 & 106 & 46 & 61 & 77 & 40 & 0.040 \\
\hline \multicolumn{12}{|l|}{$\mathrm{WV}\left(\mathrm{m} \mathrm{s}^{-1}\right)$} \\
\hline & HCA1 & 3.2 & 3.3 & 2.2 & 1.4 & 2.0 & 1.5 & 1.6 & 2.1 & 0.9 & 0.152 \\
\hline & HCA2 & 3.8 & 4.1 & 2.4 & 1.4 & 1.9 & 1.3 & 2.4 & 2.9 & 1.7 & 0.013 \\
\hline & HCA3 & 3.4 & 3.4 & 2.2 & 1.3 & 1.9 & 1.4 & 2.0 & 2.7 & 1.7 & 0.065 \\
\hline \multicolumn{12}{|c|}{$H C A l^{\mathrm{a}}$} \\
\hline \multicolumn{12}{|c|}{ Trajectories (dominating sectors) ${ }^{\mathrm{c}}$} \\
\hline \multicolumn{3}{|c|}{ Start sector $1500 \mathrm{~m}$} & 1 & & & 4 & & & $1 / 2$ & & 0.048 \\
\hline \multicolumn{3}{|c|}{ Max. residence $1500 \mathrm{~m}$} & 2 & & & $1 / 4$ & & & $1 / 2$ & & 0.059 \\
\hline \multicolumn{3}{|c|}{ Start sector $3000 \mathrm{~m}$} & $1 / 5$ & & & 4 & & & $2 / 4$ & & 0.164 \\
\hline \multicolumn{3}{|c|}{ Max. residence $3000 \mathrm{~m}$} & $2 / 4$ & & & $1 / 4$ & & & $2 / 4$ & & 0.139 \\
\hline \multicolumn{3}{|c|}{ Start sector $5000 \mathrm{~m}$} & 4 & & & 4 & & & 2 & & 0.017 \\
\hline \multicolumn{3}{|c|}{ Max. residence $5000 \mathrm{~m}$} & $1 / 5$ & & & $1 / 4$ & & & 2 & & 0.059 \\
\hline \multicolumn{12}{|c|}{$H C A 2^{\mathrm{a}}$} \\
\hline \multicolumn{12}{|c|}{ Trajectories (dominating sectors) ${ }^{\mathrm{c}}$} \\
\hline \multicolumn{3}{|c|}{ Start sector $1500 \mathrm{~m}$} & 1 & & & $2 / 4$ & & & $1 / 2$ & & 0.151 \\
\hline Max. residence & $0 \mathrm{~m}$ & & 1 & & & $1 / 2$ & & & $1 / 2$ & & 0.114 \\
\hline Start sector 300 & & & 1 & & & 4 & & & $2 / 4$ & & 0.624 \\
\hline Max. residence & $0 \mathrm{~m}$ & & $1 / 5$ & & & $2 / 4$ & & & $1 / 2$ & & 0.911 \\
\hline Start sector 500 & & & $4 / 5$ & & & $2 / 4$ & & & 2 & & 0.020 \\
\hline Max. residence & $0 \mathrm{~m}$ & & 1 & & & 4 & & & 2 & & 0.624 \\
\hline$H C A 3^{\mathrm{a}}$ & & & & & & & & & & & \\
\hline Trajectories (do & lating sec & & & & & & & & & & \\
\hline Start sector 150 & & & $1 / 2$ & & & 4 & & & 2 & & 0.034 \\
\hline Max. residence & $0 \mathrm{~m}$ & & 1 & & & 4 & & & 2 & & 0.093 \\
\hline Start sector 300 & & & 1 & & & 4 & & & 2 & & 0.207 \\
\hline Max. residence & $0 \mathrm{~m}$ & & 2 & & & 4 & & & 2 & & 0.177 \\
\hline Start sector 500 & & & $4 / 5$ & & & 4 & & & 2 & & 0.011 \\
\hline Max. residence & $0 \mathrm{~m}$ & & $1 / 5$ & & & 4 & & & 2 & & 0.093 \\
\hline
\end{tabular}

Abbreviations: $\mathrm{T}=$ Temperature, $\mathrm{RH}=$ Relative Humidity, $\mathrm{GR}=$ Global Radiation, $\mathrm{WV}=$ Wind Velocity.

${ }^{a}$ See Table 1 for parameters. Analysis was performed without chemical components. HCA1 = Zeppelin Mountain: cluster $1(n=14)$; cluster $2(n$ $=25)$; cluster $3(n=5)$. HCA2 $=$ Rabben: cluster $1(n=10)$; cluster $2(n=19)$; cluster $3(n=8)$. HCA3 = Rabben and Zeppelin: cluster $1(n=$ $13)$; cluster $2(n=15)$; cluster $3(n=7)$.

${ }^{\mathrm{b}}$ Bold entries show when the difference between the cluster is not significant based on the Kruskal-Wallis test.

${ }^{\mathrm{c}}$ Sector $1:-15^{\circ}$ to $45^{\circ}$; sector $2: 45^{\circ}$ to $150^{\circ}$; sector $3: 150^{\circ}$ to $-135^{\circ}$; sector $4:-135^{\circ}$ to $-60^{\circ}$; sector $5:-60^{\circ}$ to $-15^{\circ}$.

aerosol. Previous studies showed that soil dust in the Arctic may come from distant remote areas like Asian dessert sources and show one maximum in spring (e.g. Rahn et al., 1977; Pacyna and Ottar, 1989; Xie et al., 1999). Na, Mg and K have a marine origin and sea salt contributes largely to the Arctic aerosol over the period from October to April. Barrie and Barrie (1990) attributed this aerosol feature to a probable combination of longer residence times and a stronger sea spray source in the winter than in the 
Table 6. Calculated mean statistical values and dominating trajectory sectors for the clusters obtained by the performed HCA (ground-based with chemical components). Corresponding parameters used for the HCA are listed in Table 1

\begin{tabular}{|c|c|c|c|c|c|c|c|c|c|c|c|c|c|}
\hline & \multicolumn{3}{|c|}{ Cluster $1(n=4)$} & \multicolumn{3}{|c|}{ Cluster $2(n=4)$} & \multicolumn{3}{|c|}{ Cluster $3(n=2)$} & \multicolumn{3}{|c|}{ Cluster $4(n=21)$} & \multirow[b]{2}{*}{ Sig. ${ }^{a}$} \\
\hline & Med. & Mean & $S D$ & Med. & Mean & $S D$ & Med. & Mean & $S D$ & Med. & Mean & $S D$ & \\
\hline \multicolumn{14}{|l|}{ Zeppelin } \\
\hline \multicolumn{14}{|c|}{ Parameters of the lognormal distrib. } \\
\hline $\mathrm{n} 1\left(\mathrm{~cm}^{-3}\right)$ & 17 & 25 & 17 & 54 & 59 & 33 & 52 & 52 & 5 & 20 & 20 & 7 & 0.008 \\
\hline s1 & 1.3 & 1.3 & .0 & 1.4 & 1.4 & 0.1 & 1.23 & 1.23 & 0.0 & 1.3 & 1.3 & 0.1 & 0.063 \\
\hline $\mathrm{dp} 1(\mu \mathrm{m})$ & 0.04 & 0.04 & 0.00 & 0.05 & 0.05 & 0.00 & 0.05 & 0.05 & 0.00 & 0.05 & 0.05 & 0.00 & 0.014 \\
\hline $\mathrm{n} 2\left(\mathrm{~cm}^{-3}\right)$ & 36 & 47 & 37 & 152 & 153 & 43 & 391 & 391 & 10 & 59 & 61 & 31 & 0.003 \\
\hline $\mathrm{s} 2$ & 1.4 & 1.4 & 0.1 & 1.3 & 1.3 & 0.1 & 1.4 & 1.4 & 0.0 & 1.3 & 1.3 & 0.1 & 0.002 \\
\hline $\mathrm{dp} 2(\mu \mathrm{m})$ & 0.09 & 0.09 & 0.01 & 0.12 & 0.12 & 0.01 & 0.14 & 0.14 & 0.00 & 0.11 & 0.11 & 0.01 & 0.003 \\
\hline $\mathrm{n} 3\left(\mathrm{~cm}^{-3}\right)$ & 38 & 41 & 25 & 109 & 137 & 77 & 94 & 94 & 20 & 116 & 111 & 35 & 0.020 \\
\hline s3 & 1.4 & 1.4 & 0.1 & 1.4 & 1.4 & 0.1 & 1.3 & 1.3 & 0.0 & 1.4 & 1.4 & 0.1 & 0.054 \\
\hline $\mathrm{dp} 3(\mu \mathrm{m})$ & 0.20 & 0.20 & 0.00 & 0.21 & 0.20 & 0.02 & 0.25 & 0.25 & 0.01 & 0.17 & 0.17 & 0.02 & 0.003 \\
\hline $\operatorname{PNC}\left(\mathrm{cm}^{-3}\right)$ & 79 & 104 & 69 & 338 & 342 & 71 & 545 & 545 & 29 & 193 & 184 & 52 & 0.001 \\
\hline $\mathrm{SC} 550 \mathrm{~nm}\left(\mathrm{~km}^{-1}\right)$ & 0.0010 & 0.0010 & 0.0005 & 0.0046 & 0.0049 & 0.0006 & 0.0086 & 0.0086 & 0.0007 & 0.0027 & 0.0026 & 0.0009 & 0.000 \\
\hline $\mathrm{CR} 450 \mathrm{~nm} / 700 \mathrm{~nm}$ & 2.7 & 2.7 & 0.5 & 2.8 & 2.8 & 0.1 & 2.7 & 2.7 & 0.0 & 2.8 & 2.9 & 0.1 & 0.206 \\
\hline \multicolumn{14}{|l|}{ Rabben } \\
\hline $\operatorname{PNC}\left(\mathrm{cm}^{-3}\right)$ & 6 & 10 & 11 & 22 & 26 & 11 & 29 & 29 & 3 & 10 & 10 & 4 & 0.008 \\
\hline $\mathrm{SC} 550 \mathrm{~nm}\left(\mathrm{~km}^{-1}\right)$ & 0.0059 & 0.0076 & 0.0062 & 0.0131 & 0.0168 & 0.0090 & 0.0162 & 0.0162 & 0.0021 & 0.0063 & 0.0060 & 0.0023 & 0.008 \\
\hline $\mathrm{CR} 450 \mathrm{~nm} / 700 \mathrm{~nm}$ & 1.3 & 1.40 & 0.3 & 1.8 & 1.7 & 0.3 & 2.1 & 2.1 & 0.1 & 2.2 & 2.1 & 0.3 & 0.005 \\
\hline \multicolumn{14}{|l|}{ Meteorology } \\
\hline Temperature $\left({ }^{\circ} \mathrm{C}\right)$ & -5 & -5 & 1 & -9 & -8 & 5 & -11 & -11 & 1 & -13 & -13 & 4 & 0.011 \\
\hline $\mathrm{RH}(\%)$ & 81 & 80 & 8 & 64 & 65 & 4 & 61 & 61 & 4 & 62 & 60 & 11 & 0.040 \\
\hline Pressure & 974 & 977 & 8 & 992 & 996 & 12 & 1007 & 1007 & 5 & 1012 & 1013 & 5 & 0.001 \\
\hline $\mathrm{GR}\left(\mathrm{W} \mathrm{m}{ }^{-2}\right)$ & 46 & 48 & 24 & 65 & 73 & 41 & 56 & 56 & 7 & 109 & 110 & 49 & 0.038 \\
\hline $\mathrm{WV}\left(\mathrm{m} \mathrm{s}^{-1}\right)$ & 4.0 & 3.5 & 2.2 & 2.4 & 2.4 & 0.8 & 1.4 & 1.4 & 0.1 & 1.5 & 2.2 & 1.6 & 0.492 \\
\hline \multicolumn{14}{|c|}{$\begin{array}{l}\text { Chemical components }\left(\mathrm{ng} \mathrm{m}^{-3}\right) \\
\text { Soil }\end{array}$} \\
\hline $\mathrm{Al}$ & 41.8 & 41.8 & 13.7 & 99.3 & 99.3 & 46.7 & 102.5 & 102.5 & 8.3 & 80.7 & 87.7 & 30.7 & 0.018 \\
\hline $\mathrm{Mn}$ & 0.6 & 0.6 & 0.1 & 1.5 & 1.5 & 0.4 & 2.4 & 2.4 & 0.4 & 1.3 & 1.3 & 0.4 & 0.004 \\
\hline $\mathrm{Fe}$ & 26.0 & 26.0 & 13.7 & 40.2 & 40.2 & 6.9 & 50.5 & 50.5 & 11.5 & 41.6 & 41.6 & 11.4 & 0.052 \\
\hline \multicolumn{14}{|l|}{ Sea salt } \\
\hline $\mathrm{Na}$ & 961 & 961 & 482 & 1663 & 1663 & 717 & 354 & 354 & 278 & 179 & 260 & 210 & 0.002 \\
\hline $\mathrm{Mg}$ & 115.5 & 115.5 & 17.0 & 195.7 & 195.7 & 99.8 & 65.7 & 65.7 & 32.4 & 75.0 & 77.3 & 23.3 & 0.002 \\
\hline $\mathrm{K}$ & 54.1 & 54.1 & 2.5 & 101.1 & 101.1 & 27.9 & 84.7 & 84.7 & 21.1 & 55.1 & 52.9 & 15.3 & 0.005 \\
\hline $\mathrm{Na} / \mathrm{Mg}$ & 8.0 & 8.0 & 3.0 & 8.8 & 8.8 & 0.8 & 5.0 & 5.0 & 1.8 & 2.9 & 3.3 & 2.0 & 0.001 \\
\hline \multicolumn{14}{|l|}{ Anthropogenic } \\
\hline $\mathrm{Ti}$ & 0.0052 & 0.0052 & 0.0036 & 0.0078 & 0.0078 & 0.0007 & 0.0145 & 0.0145 & 0.0013 & 0.0045 & 0.0051 & 0.0013 & 0.006 \\
\hline$S$ & 26157 & 26157 & 16733 & 43267 & 43267 & 3674 & 50133 & 50133 & 4331 & 27165 & 29263 & 8070 & 0.018 \\
\hline $\mathrm{Ni}$ & 1.00 & 1.00 & 0.63 & 0.86 & 0.86 & 0.07 & 1.33 & 1.33 & 0.09 & 0.82 & 0.79 & 0.16 & 0.170 \\
\hline Co & 0.03 & 0.03 & .01 & 0.04 & 0.04 & 0.00 & 0.08 & 0.08 & 0.01 & 0.03 & 0.03 & 0.01 & 0.016 \\
\hline $\mathrm{Cu}$ & 3.03 & 3.03 & 2.02 & 1.55 & 1.55 & 0.03 & 3.80 & 3.80 & 0.35 & 1.56 & 1.64 & 0.36 & 0.208 \\
\hline $\mathrm{Zn}$ & 2.67 & 2.67 & 1.98 & 2.58 & 2.58 & 0.06 & 6.19 & 6.19 & 0.58 & 3.33 & 3.14 & 0.78 & 0.080 \\
\hline $\mathrm{Cd}$ & 0.03 & 0.03 & 0.01 & 0.05 & 0.05 & 0.00 & 0.13 & 0.13 & 0.00 & 0.04 & 0.04 & 0.01 & 0.007 \\
\hline $\mathrm{Pb}$ & 0.37 & 0.37 & 0.04 & 1.18 & 1.18 & 0.07 & 2.86 & 2.86 & 0.01 & 0.79 & 0.83 & 0.22 & 0.001 \\
\hline
\end{tabular}

summer. As the ratio of $\mathrm{Na} / \mathrm{Mg}$ (value around 8.3) is an indicator for sea salt, this parameter was also included in HCA4.

The corresponding dendrogram for HCA4 suggested an optimal number of four clusters (Fig. 4). Discriminant analysis was also applied and showed a clear separation. Cluster 3 covers 23 and 24 March 2000 with the highest number of anthropogenic and soil tracer components associated with the highest scattering coefficients (see Table 6). Analysis of weekly lead samples from northeast Greenland gives an indication that these high aerosol loadings are probably found throughout the region in March (Wåhlin, 2003). On 23 and 24 March 2000 (cluster 3) the corresponding backward trajectories 


\begin{tabular}{|c|c|c|c|c|c|c|c|c|c|c|c|c|c|}
\hline & \multicolumn{3}{|c|}{ Cluster $1(n=4)$} & \multicolumn{3}{|c|}{ Cluster $2(n=4)$} & \multicolumn{3}{|c|}{ Cluster $3(n=2)$} & \multicolumn{3}{|c|}{ Cluster $4(n=21)$} & \multirow[b]{2}{*}{ Sig. ${ }^{\text {a }}$} \\
\hline & Med. & Mean & $S D$ & Med. & Mean & $S D$ & Med. & Mean & $S D$ & Med. & Mean & $S D$ & \\
\hline \multicolumn{14}{|l|}{ Summary source types } \\
\hline Soil & 68 & 68 & 28 & 141 & 141 & 54 & 155 & 155 & 20 & 122 & 131 & 41 & \\
\hline Sea salt & 1131 & 1131 & 502 & 1959 & 1959 & 845 & 504 & 504 & 331 & 284 & 391 & 232 & \\
\hline Anthropogenic & 26164 & 26164 & 16737 & 43273 & 43273 & 3673 & 50147 & 50147 & 4331 & 27171 & 29269 & 8071 & \\
\hline \multicolumn{14}{|c|}{ Trajectories (dominating sectors) ${ }^{\mathrm{b}}$} \\
\hline Start sector $1500 \mathrm{~m}$ & & $2 / 4$ & & & 1 & & & 2 & & & 4 & & 0.614 \\
\hline Max. residence $1500 \mathrm{~m}$ & & 2 & & & 1 & & & 2 & & & 1 & & 0.597 \\
\hline Start sector $3000 \mathrm{~m}$ & & 5 & & & 4 & & & 2 & & & 4 & & 0.013 \\
\hline Max. residence $3000 \mathrm{~m}$ & & 4 & & & 1 & & & 2 & & & 1 & & 0.144 \\
\hline Start sector $5000 \mathrm{~m}$ & & 4 & & & None & & & 2 & & & 4 & & 0.233 \\
\hline Max. residence $5000 \mathrm{~m}$ & & 5 & & & 2 & & & 2 & & & $1 / 4$ & & 0.646 \\
\hline
\end{tabular}

Abbreviations: PNC, particle number concentration; SC, scattering coefficient; CR, colour ratio; GR, global radiation; WV, wind velocity.

${ }^{a}$ Bold entries show when the difference between the cluster is not significant based on the Kruskal-Wallis test.

${ }^{\mathrm{b}}$ Sector 1 : $-15^{\circ}$ to $45^{\circ}$; sector $2: 45^{\circ}$ to $150^{\circ}$; sector $3: 150^{\circ}$ to $-135^{\circ}$; sector $4:-135^{\circ}$ to $-60^{\circ}$; sector 5 : $-60^{\circ}$ to $-15^{\circ}$.

Table 7. Calculated mean statistical values and dominating trajectory sectors for the clusters obtained by the performed HCA (long-term sun photometer measurements). Corresponding parameters used for the HCA are listed in Table 1

\begin{tabular}{|c|c|c|c|c|c|c|c|c|c|c|}
\hline & \multicolumn{3}{|c|}{ Cluster $1(n=202)$} & \multicolumn{3}{|c|}{ Cluster $2(n=142)$} & \multicolumn{3}{|c|}{ Cluster $3(n=125)$} & \multirow[b]{2}{*}{ Sig. ${ }^{\mathrm{a}}$} \\
\hline & Median & Mean & $S D$ & Median & Mean & $S D$ & Median & Mean & $S D$ & \\
\hline AOD at $533 \mathrm{~nm}$ & 0.05 & 0.06 & 0.03 & 0.09 & 0.10 & 0.04 & 0.06 & 0.07 & 0.03 & 0.000 \\
\hline $\mathrm{AOD}$ at $1028 \mathrm{~nm}$ & 0.03 & 0.04 & 0.02 & 0.05 & 0.05 & 0.02 & 0.04 & 0.04 & 0.02 & 0.000 \\
\hline AOD at 533/ AOD at 1028 & 1.5 & 1.5 & .4 & 1.9 & 2.0 & 0.5 & 1.7 & 1.7 & 0.4 & 0.001 \\
\hline Global radiation $\left(\mathrm{W} \mathrm{m}^{-2}\right)$ & 178 & 173 & 108 & 95 & 122 & 107 & 140 & 144 & 112 & 0.014 \\
\hline Pressure (hPa) & 1011 & 1011 & 9 & 1019 & 1018 & 9 & 1012 & 1012 & 8 & 0.000 \\
\hline Temperature $\left({ }^{\circ} \mathrm{C}\right)$ & -1 & -2 & 8 & -13 & -13 & 8 & -7 & -8 & 10 & 0.000 \\
\hline $\mathrm{RH}(\%)$ & 71 & 72 & 11 & 61 & 62 & 9 & 73 & 72 & 11 & 0.000 \\
\hline Wind velocity $\left(\mathrm{m} \mathrm{s}^{-1}\right)$ & 2.5 & 3.3 & 2.4 & 2.1 & 2.8 & 1.6 & 2.8 & 3.3 & 1.8 & 0.010 \\
\hline \multicolumn{11}{|c|}{ Trajectories (dominating sector) ${ }^{\mathrm{b}}$} \\
\hline Start sector $1500 \mathrm{~m}$ & & 1 & & & 2 & & & 4 & & 0.000 \\
\hline Max. residence $1500 \mathrm{~m}$ & & 1 & & & $1 / 2$ & & & $1 / 4$ & & 0.000 \\
\hline Start sector $3000 \mathrm{~m}$ & & 1 & & & 2 & & & 4 & & 0.000 \\
\hline Max. residence $3000 \mathrm{~m}$ & & 1 & & & $1 / 2$ & & & $4 / 5$ & & 0.000 \\
\hline Start sector $5000 \mathrm{~m}$ & & $1 / 5$ & & & $1 / 2$ & & & 4 & & 0.000 \\
\hline Max. residence $5000 \mathrm{~m}$ & & 1 & & & $1 / 2$ & & & $4 / 5$ & & 0.000 \\
\hline
\end{tabular}

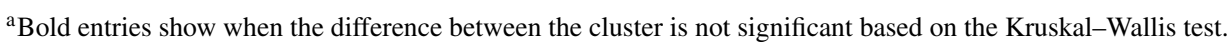

${ }^{\mathrm{b}}$ Sector 1 : $-15^{\circ}$ to $45^{\circ}$; sector $2: 45^{\circ}$ to $150^{\circ}$; sector $3: 150^{\circ}$ to $-135^{\circ}$; sector $4:-135^{\circ}$ to $-60^{\circ}$; sector 5 : $-60^{\circ}$ to $-15^{\circ}$.

show that for the different pressure levels the air masses came from central Siberia and the northern part of Europe and thus anthropogenic air masses released at mid-latitudes reached the observation area. These results are consistent with former studies on synoptic systems and preferred pathways of possible sources for high Arctic aerosol loadings (e.g. Rahn and McCaffrey, 1980; Xie et al., 1999; MacDonald et al., 2000; Eneroth et al., 2003, and references therein). The days 21 and 22 March 2000 as well as 10 and 11 April 2000 form cluster 2 with a similar number of anthropogenic components but with a much higher fraction of sea salt components. For these days the anthropogenic influences can be explained by the lowest-level trajectories that are touching northern Scotland, Scandinavia and Siberia (see Table 6). Like the second cluster, the first cluster shows an explicit influence of sea salt particles (ratios of $\mathrm{Na} / \mathrm{Mg}$ around 8). Cluster 1 consists of days where the major synoptic pressure system showed an intrusion of Atlantic air masses into the Arctic. Thus, it could be assumed that this northeastward flow of air was responsible for the registered aerosol loading at Svalbard. This could be confirmed by the analysed backward trajectories (see 
Table 8. Calculated mean statistical values for the clusters obtained by the performed HCA and dominating trajectory sectors (long-term integrating nephelometer measurements). Corresponding parameters used for the HCA are listed in Table 1

\begin{tabular}{|c|c|c|c|c|c|c|c|c|c|c|c|c|c|}
\hline & \multicolumn{3}{|c|}{ Cluster $1(n=228)$} & \multicolumn{3}{|c|}{ Cluster $2(n=258)$} & \multicolumn{3}{|c|}{ Cluster $3(n=16)$} & \multicolumn{3}{|c|}{ Cluster $4(n=218)$} & \multirow[b]{2}{*}{ Sig. ${ }^{\mathrm{a}}$} \\
\hline & Med. & Mean & $S D$ & Med. & Mean & $S D$ & Med. & Mean & $S D$ & Med. & Mean & $S D$ & \\
\hline \multicolumn{14}{|l|}{ Scattering coefficient } \\
\hline $550 \mathrm{~nm}\left(\mathrm{~km}^{-1}\right)^{\mathrm{b}}$ & 0.0027 & 0.0028 & 0.0014 & 0.0006 & 0.0008 & 0.0006 & 0.0083 & 0.0089 & 0.0025 & 0.0008 & 0.0010 & 0.0009 & 0.000 \\
\hline $450 \mathrm{~nm}\left(\mathrm{~km}^{-1}\right)^{\mathrm{b}}$ & 0.0041 & 0.0043 & 0.0021 & 0.0010 & 0.0013 & 0.0010 & 0.0125 & 0.0136 & 0.0040 & 0.0011 & 0.0016 & 0.0013 & 0.000 \\
\hline $700 \mathrm{~nm}\left(\mathrm{~km}^{-1}\right)^{\mathrm{b}}$ & 0.0015 & 0.0016 & 0.0008 & 0.0004 & 0.0005 & 0.0004 & 0.0047 & 0.0049 & 0.0014 & 0.0004 & 0.0006 & 0.0005 & 0.000 \\
\hline $\begin{array}{l}\text { Ratio } 450 / 700 \mathrm{~nm}^{\mathrm{b}} \\
\text { Meteorology }\end{array}$ & 2.9 & 2.9 & 0.3 & 2.9 & 2.8 & 0.6 & 2.8 & 2.8 & 0.3 & 2.8 & 2.6 & 0.6 & 0.000 \\
\hline Global rad. $\left(\mathrm{W} \mathrm{m}^{-2}\right)$ & 19 & 72 & 92 & 97 & 120 & 110 & 139 & 166 & 114 & 13 & 75 & 78 & 0.000 \\
\hline Pressure (hPa) & 1011 & 1010 & 11 & 1008 & 1008 & 11 & 1018 & 1015 & 7 & 1008 & 1006 & 11 & 0.000 \\
\hline Temperature $\left({ }^{\circ} \mathrm{C}\right)$ & -12 & -11 & 7 & 0 & 0 & 5 & -7 & -5 & 6 & -4 & -5 & 7 & 0.000 \\
\hline $\mathrm{RH}(\%)$ & 65 & 65 & 11 & 80 & 79 & 10 & 69 & 71 & 14 & 78 & 77 & 11 & 0.000 \\
\hline Wind velocity $\left(\mathrm{m} \mathrm{s}^{-1}\right)$ & 2.3 & 3.4 & 2.8 & 1.8 & 2.3 & 2.3 & 1.3 & 1.7 & 1.2 & 2.5 & 3.3 & 2.6 & 0.000 \\
\hline \multicolumn{14}{|c|}{ Trajectories (dominating sectors) ${ }^{\mathrm{c}}$} \\
\hline Start sector $1500 \mathrm{~m}$ & & 2 & & & 1 & & & $1 / 2$ & & & 5 & & 0.000 \\
\hline Max. residence $1500 \mathrm{~m}$ & & 1 & & & 1 & & & 1 & & & $1 / 5$ & & 0.000 \\
\hline Start sector $3000 \mathrm{~m}$ & & 2 & & & 1 & & & 1 & & & $4 / 5$ & & 0.000 \\
\hline Max. residence $3000 \mathrm{~m}$ & & 1 & & & 1 & & & 1 & & & 5 & & 0.000 \\
\hline Start sector $5000 \mathrm{~m}$ & & $1 / 2$ & & & 1 & & & 2 & & & 5 & & 0.000 \\
\hline Max. residence $5000 \mathrm{~m}$ & & 1 & & & 1 & & & 1 & & & $4 / 5$ & & 0.000 \\
\hline
\end{tabular}

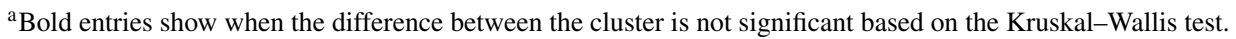

${ }^{\mathrm{b}}$ Scattering coefficient and colour ratio of integrating nephelometer measurements from Zeppelin Mountain.

${ }^{\mathrm{c}}$ Sector $1:-15^{\circ}$ to $45^{\circ}$; sector $2: 45^{\circ}$ to $150^{\circ}$; sector $3: 150^{\circ}$ to $-135^{\circ}$; sector $4:-135^{\circ}$ to $-60^{\circ}$; sector $5:-60^{\circ}$ to $-15^{\circ}$.

Table 6). The first and the fourth cluster have a similar amount of total anthropogenic tracer component whereas cluster 4 has approximately twice as much soil component and about four times less sea salt component. Interesting are still high amounts of anthropogenic species and an increased scattering coefficient for both clusters, although the four-day backward trajectories used do not pass over any obvious source of pollution. Cluster 4 is characterized by air masses coming mainly from the northwest (see Table 6). This behaviour can be attributed to the fact that precipitation scavenging is less pronounced in winter, so that aerosol residence times in the Arctic atmosphere reach their maximum (Carlson, 1981; Heidam, 1984). During the cold period of the year, aerosol residence times range between 3 and 7 weeks compared with 3 to 7 days in the warm period (Sirois and Barrie, 1999; Nilson and Rannik, 2001). The analysed time-series of weekly lead concentrations in Greenland underline this statement, where almost stable concentrations were found throughout April before they decreased at the end of the month from 1 to $0.5 \mathrm{ng} \mathrm{m}^{-3}$ (Wåhlin, 2003). Within the clusters differences occurred for the parameters of the aerosol size distribution, which might be the result of the different aerosol sources discussed above. By including the chemical components in the HCA an additional cluster (cluster 2) was identified, which shows the greatest quantity of sea-salt components but also increased anthropogenic tracers. Within HCA1 to HCA3 these days were classified into cluster 3 .

\subsection{Long-term time-series from Koldewey and Zeppelin Mountain}

Having in mind the goal of linking together the extensive shortterm measurements (ASTAR) with available routine long-term measurements the HCA was also applied to the two available long-term data sets (see Table 1). This puts the obtained classification of the ASTAR period into a broader context and enables us to validate their application and transfer to a long-term scale. HCA for the long-term AOD data record was applied by incorporating all parameters mentioned in Table 1. Three clusters were determined. A discriminant analysis was performed on the basis of the three-class hypothesis according to the results of the cluster analysis. The three cluster points were arranged in the a priori classes. The graphical representation of these classes in the plane of the two non-elementary discriminant functions highlights the complete separation. The correct classification confirms the classes of different aerosol states (see Fig. 5a). The three clusters characterizing statistical values are listed in Table 7. Siberia and Europe are the dominating trajectory start sectors for the cluster with the highest AOD values (cluster 2 ). This is in agreement with cluster 3 of the ASTAR database. The determined mean values for cluster 2 are in the range of AOD measurements reported from other authors for high Arctic aerosol loadings (Shaw, 1975; Freud, 1983; Dutton et al., 1989; Leiterer et al., 1992; Herber et al., 2002; Eneroth et al., 2003). 
Table 9. Calculated mean statistical values and dominating trajectory sectors for the clusters obtained by the performed HCA (long-term integrating nephelometer and sun photometer measurements). Corresponding parameters used for the HCA are listed in Table 1

\begin{tabular}{|c|c|c|c|c|c|c|c|c|c|c|}
\hline & \multicolumn{3}{|c|}{ Cluster $1(n=41)$} & \multicolumn{3}{|c|}{ Cluster $2(n=48)$} & \multicolumn{4}{|c|}{ Cluster $3(n=4)$} \\
\hline & Median & Mean & $S D$ & Median & Mean & $S D$ & Median & Mean & $S D$ & Sig. ${ }^{\text {a }}$ \\
\hline \multicolumn{11}{|l|}{ Integrating nephelometer ${ }^{\mathrm{b}}$} \\
\hline $550 \mathrm{~nm}\left(\mathrm{~km}^{-1}\right)$ & 0.0009 & 0.0015 & 0.0014 & 0.0032 & 0.0032 & 0.0012 & 0.0116 & 0.0116 & 0.0022 & 0.000 \\
\hline $450 \mathrm{~nm}\left(\mathrm{~km}^{-1}\right)$ & 0.0016 & 0.0023 & 0.0021 & 0.0049 & 0.0051 & 0.0020 & 0.0186 & 0.0182 & 0.0037 & 0.000 \\
\hline $700 \mathrm{~nm}\left(\mathrm{~km}^{-1}\right)$ & 0.0005 & 0.0009 & 0.0008 & 0.0017 & 0.0018 & 0.0007 & 0.0060 & 0.0060 & 0.0010 & 0.000 \\
\hline $\begin{array}{l}\text { Ratio } 450 \mathrm{~nm} / 700 \mathrm{~nm} \\
\text { Sun photometer }\end{array}$ & 2.7 & 2.7 & 0.5 & 2.9 & 2.9 & 0.1 & 3.0 & 3.0 & 0.2 & 0.012 \\
\hline $\mathrm{AOD}$ at $533 \mathrm{~nm}$ & 0.05 & 0.056 & 0.02 & 0.09 & 0.09 & 0.02 & 0.14 & 0.14 & 0.04 & 0.000 \\
\hline $\mathrm{AOD}$ at $1028 \mathrm{~nm}$ & 0.04 & 0.04 & 0.02 & 0.05 & 0.05 & 0.01 & 0.07 & 0.07 & 0.02 & 0.003 \\
\hline $\mathrm{AOD}$ at 533/AOD at 1028 & 1.3 & 1.3 & 0.3 & 1.8 & 1.8 & 0.5 & 1.9 & 1.1 & 0.5 & 0.000 \\
\hline \multicolumn{11}{|l|}{ Meteorology } \\
\hline Global rad. $\left(\mathrm{W} \mathrm{m}^{-2}\right)$ & 240 & 225 & 81 & 136 & 161 & 81 & 254 & 210 & 107 & 0.002 \\
\hline Pressure (hPa) & 1007 & 1007 & 9 & 1015 & 1015 & 8 & 1010 & 1010 & 9 & 0.000 \\
\hline Temperature $\left({ }^{\circ} \mathrm{C}\right)$ & -1 & -1 & 4 & -12 & -12 & 6 & -7 & -8 & 2 & 0.000 \\
\hline $\mathrm{RH}(\%)$ & 78 & 77 & 9 & 62 & 62 & 8 & 65 & 66 & 2 & 0.000 \\
\hline Wind velocity $\left(\mathrm{m} \mathrm{s}^{-1}\right)$ & 1.9 & 3.0 & 2.4 & 1.7 & 2.0 & 1.4 & 1.3 & 1.3 & 0.1 & 0.144 \\
\hline \multicolumn{11}{|c|}{ Trajectories (dominating sectors) ${ }^{\mathrm{c}}$} \\
\hline Start sector $1500 \mathrm{~m}$ & & 1 & & & 1 & & & 2 & & 0.739 \\
\hline Max. residence $1500 \mathrm{~m}$ & & 1 & & & 1 & & & 1 & & 0.566 \\
\hline Start sector $3000 \mathrm{~m}$ & & None & & & 4 & & & 4 & & 0.947 \\
\hline Max. residence $3000 \mathrm{~m}$ & & 1 & & & 1 & & & 1 & & 0.377 \\
\hline Start sector $5000 \mathrm{~m}$ & & $1 / 5$ & & & $2 / 4$ & & & $2 / 4$ & & 0.492 \\
\hline Max. residence 5000 m & & $1 / 2$ & & & $1 / 2$ & & & $1 / 2$ & & 0.679 \\
\hline
\end{tabular}

${ }^{a}$ Bold entries show when the difference between the cluster is not significant based on the Kruskal-Wallis test.

${ }^{\mathrm{b}}$ Scattering coefficient and colour ratio of integrating nephelometer measurements from Zeppelin Mountain.

${ }^{\mathrm{c}}$ Sector 1 : $-15^{\circ}$ to $45^{\circ}$; sector $2: 45^{\circ}$ to $150^{\circ}$; sector $3: 150^{\circ}$ to $-135^{\circ}$; sector $4:-135^{\circ}$ to $-60^{\circ}$; sector $5:-60^{\circ}$ to $-15^{\circ}$.

Table 10. Calculated mean statistical values and dominating trajectory sectors for the clusters obtained by the performed HCA (aircraft measurements). Corresponding parameters used for the HCA are listed in Table 1

\begin{tabular}{|c|c|c|c|c|c|c|c|c|c|c|}
\hline & \multicolumn{3}{|c|}{ Cluster $1(n=29)$} & \multicolumn{3}{|c|}{ Cluster $2(n=91)$} & \multicolumn{3}{|c|}{ Cluster $3(n=3)$} & \multirow[b]{2}{*}{ Sig. ${ }^{a}$} \\
\hline & Median & Mean & $S D$ & Median & Mean & $S D$ & Median & Mean & $S D$ & \\
\hline Extinction coeff. $\left(\mathrm{km}^{-1}\right)$ & 0.0194 & 0.0236 & 0.0182 & 0.0038 & 0.0045 & 0.0040 & 0.0472 & 0.0460 & 0.0071 & 0.000 \\
\hline Scattering coeff. $\left(\mathrm{km}^{-1}\right)$ & 0.0077 & 0.0079 & 0.0029 & 0.0019 & 0.0023 & 0.0012 & 0.0254 & 0.0245 & 0.0023 & 0.000 \\
\hline Absorption coeff. $\left(\mathrm{km}^{-1}\right)$ & 0.00081 & 0.00088 & 0.00041 & 0.00053 & 0.00058 & 0.00020 & 0.00353 & 0.00342 & 0.00080 & 0.000 \\
\hline Particle number $\left(\mathrm{cm}^{-3}\right)$ & 41 & 40 & 5 & 24 & 25 & 6 & 52 & 52 & 1 & 0.000 \\
\hline \multicolumn{11}{|l|}{ Concentration } \\
\hline $\mathrm{RH}(\%)$ & 46 & 47 & 11 & 23 & 24 & 9 & 49 & 48 & 4 & 0.000 \\
\hline \multicolumn{11}{|c|}{ Trajectories (dominating sectors) $)^{b}$} \\
\hline Start sector & & $2 / 3$ & & $2 / 4$ & & & & & 2 & 0.220 \\
\hline Max. residence & & $1 / 2$ & & $1 / 4$ & & & & & 2 & 0.318 \\
\hline
\end{tabular}

${ }^{a}$ Bold entries show when the difference between the cluster is not significant based on the Kruskal-Wallis test.

${ }^{\mathrm{b}}$ Sector 1 : $-15^{\circ}$ to $45^{\circ}$; sector $2: 45^{\circ}$ to $150^{\circ}$; sector $3: 150^{\circ}$ to $-135^{\circ}$; sector $4:-135^{\circ}$ to $-60^{\circ}$; sector $5:-60^{\circ}$ to $-15^{\circ}$.

The other two clusters have much smaller and approximately similar AOD values but are characterized by different dominant trajectory sectors. Compared with the short-term ASTAR data set there is a statistical significant difference between the air mass history of the three determined clusters.
The next data set studied was the long-term integrating nephelometer measurements from Zeppelin Mountain (see Fig. 1 and Table 1 for details on the data set), which deliver continuous measured aerosol light-scattering properties at a height level of $475 \mathrm{~m}$ above sea level. The HCA reveals four distinct clusters 

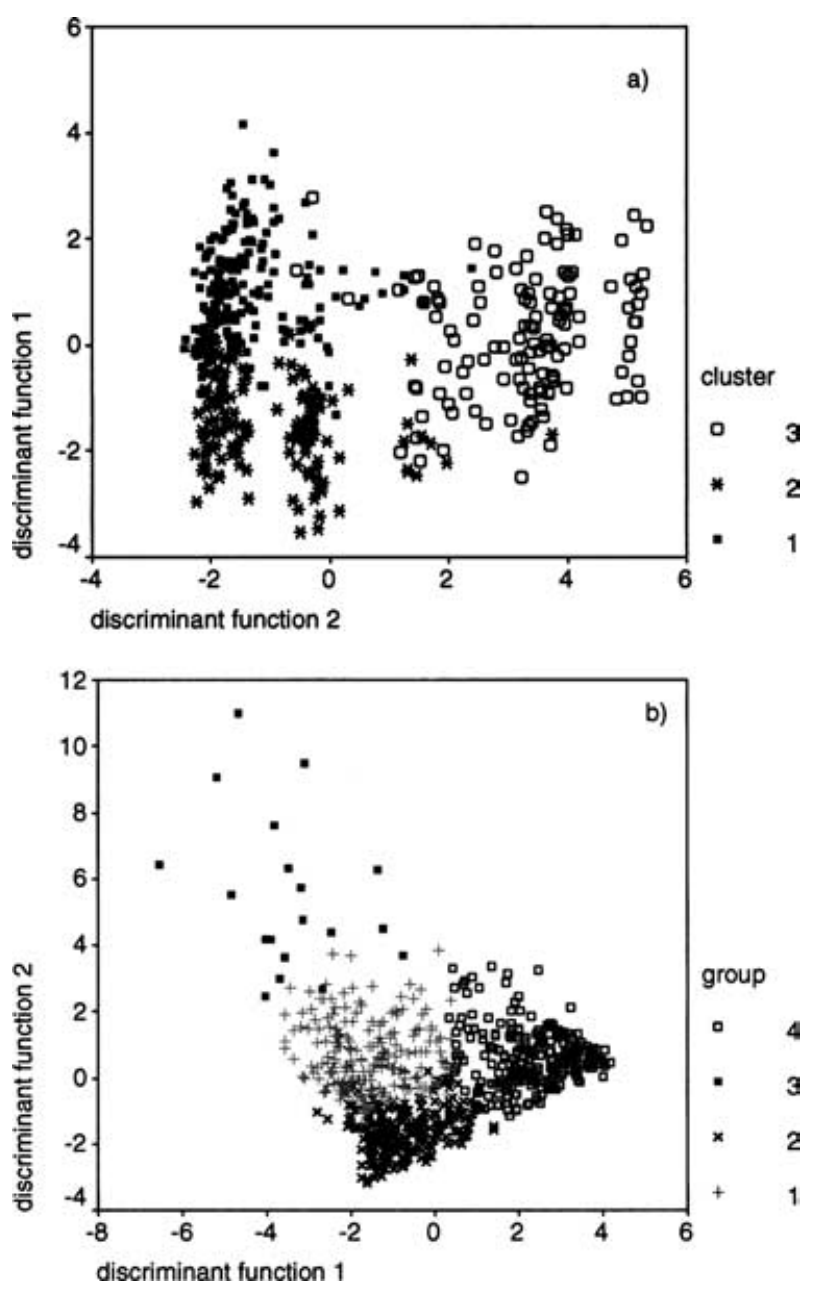

Fig 5. Results of the discriminant analysis for the performed HCA for both long-term data sets (parameters used for the corresponding HCA are listed in Table 1). (a) Sun photometer measurements from Koldewey. (b) Integrating nephelometer measurements from Zeppelin Mountain.

of the data set. The discriminant analysis helps to assess the homogeneity and separateness of the clusters. The clusters are statistically different and the data points can be separated (see Table 8 and Fig. 5b). Table 8 presents the characteristic mean values for each cluster. The cluster with the highest scattering coefficients (cluster 3 ) is accompanied with low wind velocities and the highest values for the global radiation (see Table 8). The two clusters with the lowest scattering coefficients (clusters 2 and 4) show different air mass origins and thus are in good agreement with the results obtained for the AOD data set (clusters 1 and 3). Finally, the HCA was applied to the combination of both long-term measurements (see Table 9).

\subsection{Vertical time-series during ASTAR}

The classifications presented above are related to ground-based measurements. As a part of the ASTAR 2000 campaign 17 ver- tical profiles of aerosol properties were measured within the latitude range from $74^{\circ} \mathrm{N}$ to $79^{\circ} \mathrm{N}$, and within the longitude range from $8^{\circ} \mathrm{E}$ to $24^{\circ} \mathrm{E}$ (see Table 3 ). For the conducted flights the hierarchical HCA was applied to the simultaneous microphysical and optical measurements (see Tables 1 and 3 for details). Three different kinds of cluster could be distinguished and were tested for their significance (see Table 10). Mean cluster values based on the HCA results are listed in Table 10. These mean cluster values are comparable to values reported in other studies (Kahn, 1981; Radke et al., 1984; Ottar et al., 1986; Brock et al., 1990; Khattatov et al., 1997; Nagel et al., 1998). For example, Clarke et al. (1984) determined the mean scattering coefficient and absorption coefficient (at $550 \mathrm{~nm}$ ) for haze layers of around $0.016 \mathrm{~km}^{-1}$ and $0.0026 \mathrm{~km}^{-1}$, respectively. Dutton et al. (1989) reported extinction values $(500 \mathrm{~nm})$ for layers with high aerosol loadings from less than 0.005 to $0.2 \mathrm{~km}^{-1}$ and typical values were around $0.03 \mathrm{~km}^{-1}$. Leiterer et al. (1997) calculated similar extinction coefficients for haze layers. However, we note that these authors defined aerosol layers using different threshold values.

\section{Summary}

Taken together, the entire ASTAR data base used for this study contains variability in the data that essentially can be explained by three to four clusters obtained with the help of a HCA. The temporal and vertical variation expressed in terms of cluster results is visualized in Fig. 6. For the ground-based data sets each day is coloured according to the cluster to which the day belongs. Figure 6a demonstrates that days within the ASTAR campaign are classified into distinct and similar clusters based on the four HCAs performed. As shown above, the pattern obtained by the four HCAs is consistent with the synoptic situations and analysed trajectory pathways.

For the ASTAR time period the day clustering based on the different HCAs of the two long-term data sets is depicted in Fig. 6b. It can be concluded that the clustering of the ASTAR campaign is consistent with the clustering obtained by the analysis of the long-term data sets. Most probably the HCA performed for the integrating nephelometer data set result in one more cluster due to the larger database covering the full annul cycle and thus the possibility of encountering the entire aerosol variation. The differences might be also attributed to the fact that the sun photometer measurements provide column information about the atmospheric aerosol loading under clear sky conditions, whereas the in situ ground-based observations provide continuous measured information about the boundary layer. By combining column information with ground-based related measurements one faces the problem that the same AOD can be recorded for different atmospheric conditions. This in turn explains why the HCA performed for the sun photometer data set clearly shows clusters with high and low aerosol loading but cannot identify a cluster with an intermediate aerosol loading as the integrating nephelometer does. 


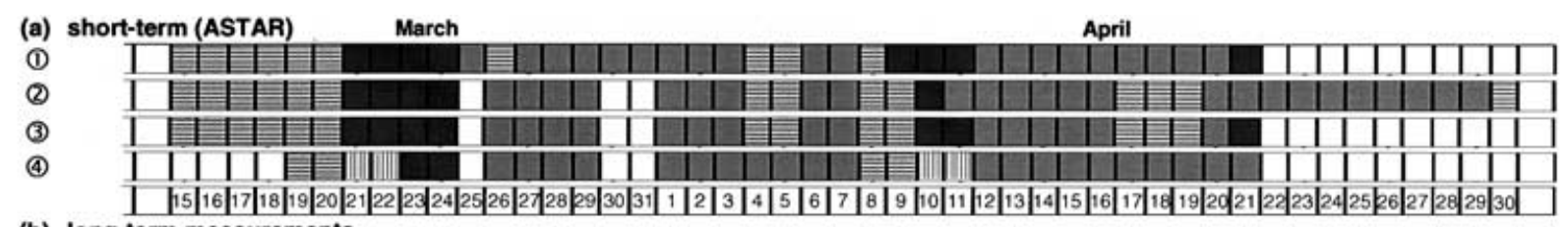

(b) long-term measurements

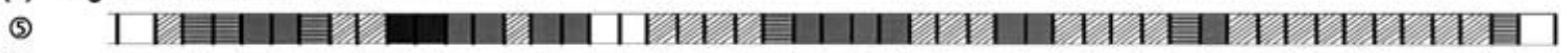

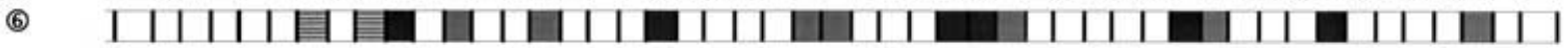

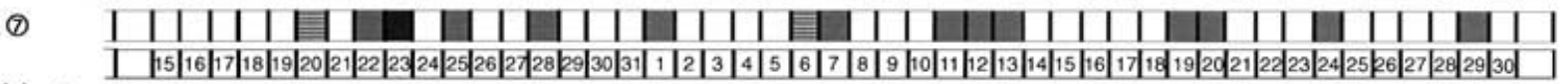

(c) aircraft measurements

(8)

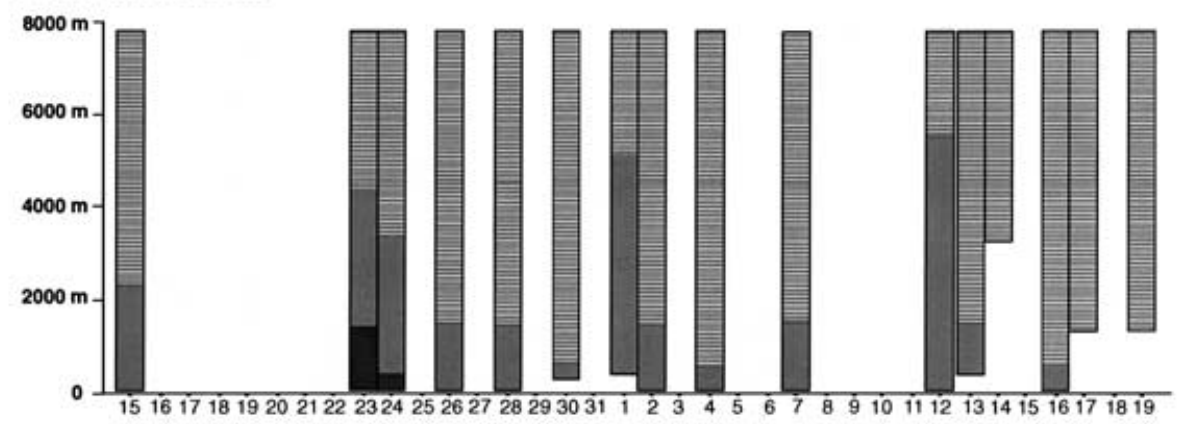

(1) = Rabben (white=no data; cluster $1=$ light grey horizontal lined; cluster $2=$ dark grey; cluster $3=$ black - for details see Table 4 and Table 5)

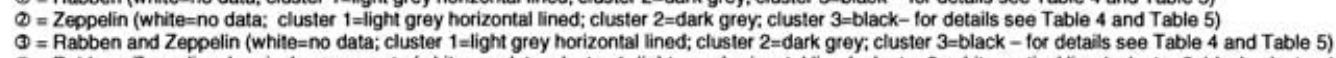

(1) = Rabben, Zeppelin, chemical components (white=no data; cluster 1=light grey horizontal lined; cluster $2=$ white vertical lined; cluster $3=b l a c k$; cluster $4=$ dark grey - for details see Table 6 ). $\Phi=$ Integrating Nephelometer Zeppelin (white=no data; cluster 1 = white diagonal lined; cluster 2 = light grey horizontal lined; cluster 3 = black; cluster $4=$ dark grey - for details see Table 8 ) (1) = Sun photometer (white=no data; cluster 1=light grey horizontal lined; cluster 2=black; cluster $3=$ dark grey - for details see Table 7 )

$\Phi=$ Integrating Nephelometer Zeppelin and Sun photometer (white=no data; cluster $1=$ light grey horizontal; cluster 2=dark grey; cluster $3=$ black - for details see Table 9 )

(7) = Aircraft measurements (colours represent: cluster 1=dark grey; cluster 2=light grey horizontal lined; cluster 3=black - for details see Table 10)

Fig 6. Clusters obtained for the time period 15 March 2000 to 30 April 2000 (ASTAR) for the different locations and monitoring systems. Each day is shaded according to the cluster it belongs to based on the different HCAs performed for the ground-based measurements during the ASTAR campaign and the long-term measurements. Airborne measurements are shaded according to the obtained vertical clusters. The input parameters of each performed HCA are listed in Table 1.

Figure $6 \mathrm{c}$ shows the clusters determined for the airborne measurements as a function of altitude. The HCA enables one to compare the different vertical profiles based on a combination of all information included in the different parameters. As for the ground-based analysis, 23 March and 24 March 2000 form a cluster at the lower height level with the highest mean values for the investigated aerosol parameters (cluster 3). For 23 March 2000 the layer was identifiable up to a height of almost $1.5 \mathrm{~km}$. Above this layer an intermediate polluted layer (cluster 2) was determined up to a height of $4.5 \mathrm{~km}$. The following days do not show any strong signs of pollution aloft. This is in good agreement with the results from the ground-based HCA where the trajectory analysis showed that there was no subsidence bringing polluted air masses from aloft to ground level. The only higher aerosol loading aloft is registered for 1 and 12 April 2000.

\section{Conclusion}

Compared with other areas of the world, measurements of aerosol properties in the Arctic are sparse. This study was designed to achieve a meaningful data grouping in order to link together the information from an existing Arctic data set and has focused attention on the temporal and vertical variation in the atmospheric aerosol loading at one measurement site in the European Arctic. A cluster analysis was applied to systematically study different aerosol loadings and to group data in categories. An advantage of this method is that information contained in complex data sets of different parameters is analysed simultaneously. The data set analysed within this study consists of different independent microphysical, optical and chemical ground-based as well as airborne measurements of simultaneous recorded aerosol parameters during a 2-month intensive measurement campaign. Furthermore, two long-term aerosol data sets and meteorological parameters as well as trajectory analysis were incorporated into the investigations. The resulting clusters were tested for statistical difference and mean cluster-defining values were calculated. The performed analysis showed a distinct and meaningful clustering.

The HCA method used in this study was shown to be effective in reducing complex information contained in a data set to a few clusters representing typical states of the aerosol properties. This clustering helps in linking different data sets that are intermittently non-overlapping in space and time. As such, the 
technique provides a tool by which it is possible to extend the coverage of data in time and space to make better use of the data to initialize and verify numerical models. Difficulties with clustering ground-based sun photometer measurements with other ground-based in situ measurements during intermediate aerosol loadings point to the importance of knowing the vertical structure of the aerosol. With regard to the needs of regional climate models, for example, and thus the assessment of the climatic impact of Arctic aerosols these are essential and important results.

\section{Acknowledgments}

We would like to thank all institutes who made their data available to us. Their cooperation with us opened up the possibility of performing this study. We also thank our colleagues for fruitful discussions. Gaye Brunker and Emily Todd are acknowledged for their careful reading of the manuscript. We would like to acknowledge the Swedish Environmental Protection Agency for supporting the activities at the Zeppelin Station. Finally, we would like to thank the reviewers for their useful comments.

\section{References}

Anderson, T. L., Covert, D. S., Marshall, S. F., Laucks, M. L., Charlson, R. J. et al. 1996. Performance characteristics of a high-sensitivity, three-wavelength, total scatter/backscatter nephelometer. J. Atmos. Ocean. Technol., 13, 967-986.

Ansmann, A., Riebesell, M. and Weitkamp, C. 1990. Measurement of atmospheric aerosol extinction profiles with a Raman lidar. Opt. Lett. 15, 746-748.

Barrie, L. A. 1986. Arctic air pollution: an overview of current knowledge. Atmos. Environ. 20, 643-663.

Barrie, L. A. and Barrie, M. L. 1990. Chemical components of lower tropospheric aerosols in the high Arctic: six years of observation. $J$. Atmos. Chem. 11, 211-226.

Blanchet, J. P. 1989. Toward estimation of climate effects due to Arctic aerosols. Atmos. Environ. 23, 2609-2625.

Bodhaine, B. A. and Dutton, E. G. 1993. A long-term decrease in Arctic haze at Barrow, Alaska. Geophys. Res. Lett. 20, 947-950.

Bond, T. C., Anderson, T. L. and Campbell, D. 1999. Calibration and intercomparison of filter-based measurements of visible light absorption by aerosols. Aerosol Sci. Technol. 30, 582-600.

Brock, C. A., Radke, L. F. and Hobbs, P. V. 1990. Sulfur in particles in Arctic haze derived by airborne in situ and lidar measurements. $J$. Geophys. Res. 95, 22 369-22 387.

Carlson, T. N. 1981. Speculations on the movement of polluted air to the Arctic. Atmos. Environ. 15, 1407-1419.

Clarke, A. D., Charlson, R. J. and Radke, L. F. 1984. Airborne observations of Arctic aerosol, IV: optical properties of Arctic haze. $J$. Geophys. Res. 11, 405-408.

Conover, W. J. 1971. Practical Nonparametric Statistics. Wiley, New York.

de Miranda, R. M., Andrade, M. F., Worobiec A. and Grieken van, R. 2002. Characterisation of aerosol particles in the São Paulo Metropolitan Area. Atmos. Environ. 36, 345-352.
Dethloff, K., Rinke, A., Lehmann, R., Christensen, J. H., Botzet, M. et al. 1996. Regional climate model of the Arctic atmosphere. J. Geophys. Res. 101, 23 401-23 422.

Dethloff, K., Schwager, M., Christensen, J. H., Kiilsholm, S., Rinke, A. et al. 2002. Recent Greenland accumulation estimated from regional climate model simulations and ice core analysis. J. Climate 15, 28212832.

Dorn, W., Dethloff, K. and Rinke, A. 2003. Competition of NAO regime changes and increasing greenhouse gases and aerosols with respect to Arctic climate estimate. Clim. Dyn. 21. 447-458.

Draxler, R. R. and Rolph, G. D. 2003. HYSPLIT (HYbrid Single-Particle Lagrangian Integrated Trajectory) model http://www.arl.noaa.gov/ready/hysplit4.html. NOAA Air Resources Laboratory, Silver Spring, MD.

Dreiling, V. and Friedrich, B. 1997. Spatial distribution of the arctic haze aerosol size distribution in western and eastern Arctic. Atmos. Res. 44, $133-152$.

Dreiling, V. and Jaenicke, R. 1995. German-Russian Arctic Haze Project: vertical profiles of aerosol integral parameters in spring and summer and derived size distributions. J. Aerosol Sci. 26, 591592.

Dutton, E. G., Luise de, J. J. and Herbert, G. 1989. Shortwave aerosol optical depth of Arctic haze measured on board the NOAA WP-3D during AGASP-II, April 1986. J. Atmos. Chem. 9, 71-79.

Emery, C. A., Haberle, R. and Ackermann, T. P. 1992. A one-dimensional modelling study of carbonaceous haze effects on the springtime Arctic environment. J. Geophys. Res. 97, 20 599-20613.

Eneroth, K., Kjellström, E. and Holmén, K. 2003. A trajectory climatology for Svalbard; investigation how atmospheric flow patterns influence observed tracer concentrations. Phys. Chem. Earth 28, 11911203.

Fovell, R. and Fovell, M. Y. 1993. Climate zones of the conterminous United States defined using cluster analysis. J. Climate 6, 2103-2135.

Freud, J. 1983. Aerosol optical depth in the Canadian Arctic. Atmos. Ocean 21, 158-167.

Hara, K., Osada, K., Nishita, C., Yamagata, S., Yamanouchi, T. et al. 2002. Vertical variations of sea-salt modification in the boundary layer of Arctic spring during the ASTAR 2000 campaign. Tellus 54B, 361376.

Hara, K., Yamagata, S., Yamanouchi, T., Sato, K., Herber, A. et al. 2003. Mixing states of individual aerosol particles in spring Arctic troposphere during the ASTAR 2000 campaign. J. Geophys. Res. 108, 4209, doi:10.1029/2002JD002513.

Harris, J. and Kahl, J. 1994. Analysis of 10 days isentropic flow patterns for Barrow, Alaska: 1985-1992. J. Geophys. Res. 99, 25 845-25855.

Hegg, D. A., Hobbs, P. V., Gasso, S., Nance, J. D. and Rangno, A. L. 1996. Aerosol measurements in the Arctic relevant to direct and indirect forcing. J. Geophys. Res. 101, 23 349-23 363.

Heidam, N. Z. 1984. The composition of the Arctic aerosol. Atmos. Environ. 18, 329-343.

Heintzenberg, J. 1981. The chemical composition of Arctic haze at NyAlesund, Spitzbergen. Tellus 33, 162-171.

Heintzenberg, J., Ström, J. and Ogren, J. A. 1991. Vertical profiles of aerosol properties in the summer troposphere of central Europe, Scandinavia and the Svalbard area. Atmos. Environ. 25A, 621-627.

Herber, A., Thomason, L. W., Gernandt, H., Leiterer, U., Nagel, D. et al. 2002. Continuous day and night aerosol optical depth 
observations in the Arctic between 1991 and 1999. J. Geophys. Res. 107(D10) doi:10.1029/2001JD000536.

Ho, K. F., Lee, S. C., Gloria, M. and Chiu, Y. 2002. Characterization of selected volatile organic compounds, polycyclic aromatic hydrocarbons and carbonyl compounds at a roadside monitoring station. Atmos. Environ. 36, 57-65.

Hopfer, J. F., Worthy, D. E., Barrie, L. A. and Trivett, N. B. 1994. Atmospheric observation of aerosol black carbon, carbon dioxide and methane in the high Arctic. Atmos. Environ. 28, 3047-3054.

IPCC 2001. Climate Change: the Scientific Basis 2001, Chapter 5. Cambridge University Press, New York.

Jaeschke, W., Salkowski, T., Dierssen, J. P., Truembach, J. V., Krischke, U. et al. 1999. Measurements of trace substances in the Arctic troposphere as potential precursors and constituents of Arctic haze. $J$. Atmos. Chem. 34, 291-319.

Jokinen, V. and Mäkelä, J. M. 1997. Closed-loop arrangement with critical orifice for DMA sheath/excess flow system. J. Aerosol Sci. 28(4), 643-648.

Kahn, K. A. 1981. Relative importance of North America and Eurasia as sources of Arctic aerosols. Atmos. Environ. 15, 1447-1455.

Khattatov, V. U., Tyabotov, A. E., Alekseyev, A. P., Postnov, A. A. and Stulov, E. A. 1997. Aircraft lidar studies of the Arctic haze and their meteorological interpretation. Atmos. Res. 44, 99-111.

Knutson, E. O. and Whitby, K. T. 1975. Aerosol classification by electric mobility: Apparatus, theory and applications. J. Aerosol Sci. 6, 443451.

Koepke, P., Hegg, M., Schult, I. and Shettle, E. P. 1997. Global Aerosol Data Set, MPI Report 243, 1-44. Max-Planck Institut fur Meteorologie, Hamburg, Germany.

Krasnova, T. M., Skouratov, S. N. and Vinnichenko, N. K. 1997. Height dependent absorption of solar radiation in the Arctic atmosphere. Atmos. Res. 44, 61-71.

Kriews, M. and Schrems, O. 1998. Aerosol sampling depending on precipitation at Spitsbergen. J. Aerosol Sci. 29, 685-686.

Leck, C., Nilsson, E. D., Bigg, E. K. and Bäcklin, L. 2001. Atmospheric program on the Arctic Ocean Expedition 1996 (AOE-96): an overview of scientific goals, experimental approach, and instruments. J. Geophys. Res. 106(D23), 32 051-32067.

Leiterer, U., Nagel D. and Stolte R. 1997. Typical vertical profiles of aerosol spectral extinction coefficients derived from observations of direct solar radiation extinction during the aircraft experiments Arctic Haze 94/95 and Merisec 93/94. Atmos. Res. 44, 73-88.

Leiterer, U., Weller, M. and Herber, A. 1992. Global changes of aerosols-ground-based monitoring of the optical thickness in polar regions and central Europe. Ber. Bunsenges. Phys. Chem. 96, $377-$ 380.

Luedke, C., Hoffmann, E., Skole, J. and Kriews, M. 1999. Determination of trace metals in size fractionated particles from Arctic air by electrothermal vaporization inductively coupled plasma mass spectrometry. J. Anal. At. Spectrom. 14, 1685-1690.

MacDonald, R. W., Barrie, L. A., Bidleman, T. F., Diamond, M. L., Gregor, D. J. et al. 2000. Contaminants in the Canadian Arctic: 5 years of progress in understanding sources, occurrence and pathways. Sci. Total Environ. 254, 93-234.

Nagel, D., Herber, A., Thomason, L. W. and Leiterer, U. 1998. Vertical distribution of the spectral aerosol optical depth in the Arctic from 1993 to 1996. J. Geophys. Res. 103(D2), 1857-1870.
Nakajima, T., Tonna, T., Rao, R., Boi, P., Kaufman, Y. et al. 1996. Use of sky brightness measurements from ground for remote sensing of particulate polydispersions. Appl. Opt. 35, 2672-2686.

Nilson, E. D. and Rannik, Ü. 2001. Turbulent aerosol fluxes over the Arctic ocean. 1. Dry deposition over sea and pack ice. J. Geophys. Res. 106(D23), 32 125-32 137.

Norman, A. L., Barrie, L. A., Toom-Sauntry, D., Sirois, A., Krouse, H. R. et al. 1999. Sources of aerosol sulphate at Alert: apportionment using stable isotopes. J. Geophys. Res. 103(D15), 19045-19057.

Ottar, B., Pacyna, J. M. and Berg, T. C. 1986. Aircraft measurements of air pollution in the Norwegian Arctic. Atmos. Environ. 20, 87-100.

Pacyna, J. M. and Ottar, B. 1989. Origin of natural constituents in the Arctic aerosols. Atmos. Environ. 23, 809-815.

Parungo, F. P., Clarence, T., Sheridan, N. and Sheridan, P. 1990. Aerosol characteristics of Arctic aerosols sampled during AGASP-II. Atmos. Environ. 24A, 937-949.

Polissar, A. V., Hopke, P. K., Paatero, P., Kaufmann, Y. J., Haal, D. K. et al. 1999. The aerosol at Barrow, Alaska: long-term trends and source location. Atmos. Environ. 33, 2441-2458.

Pueschel, R. F. and Kinne, S. A. 1995. Physical and radiative properties of Arctic atmospheric aerosols. Sci. Total Environ. 160/161, 811-824.

Quinn, P. K., Miller, T. L. and Bates, T. S. 2002. A 3-year record of simultaneous measured aerosol chemical and optical properties at Barrow, Alaska. J. Geophys. Res. 107(D11), doi:101029/2001JD001248.

Raatz, W. E. and Schnell, R. C. 1984. Aerosol distribution and arctic aerosol front during AGASP: Norwegian Arctic. Phys. Res. Lett. 11, 373-376.

Radke, L. F., Lyons, J. H., Hegg, D. A. and Hobbs, P. V. 1984. Airborne observations of Arctic aerosols. I: characteristics of Arctic Haze. $J$. Geophys. Res. 11, 393-396.

Rahn, K. A., Borys, R. D. and Shaw, G. E. 1977. The Asian source of Arctic haze bands. Nature 268, 713-715.

Rahn, K. A. and McCaffrey, R. J. 1980. On the origin and transport of the winter Arctic aerosol. Ann. N.Y. Acad. Sci. 338, 486-503.

Ricard, V., Jaffrezo, J. L., Kerminen, V. M., Hillamo, R. E., Sillanpaa, M. et al. 2002. Two years of continuous aerosol measurements in northern Finland. J. Geophys. Res. 107(D11), doi:101029/2001JD000952.

Rinke, A., Lynch, A. H. and Dethloff, K. 2000. Intercomparison of Arctic regional climate simulations: case studies of January and June 1990, J. Geophys. Res. 105, 29 669-29683.

Rolph, G. D. 2003. Real-time Environmental Applications and Display System (READY). http://www.arl.noaa.gov/ready/hysplit4.html. NOAA Air Resources Laboratory, Silver Spring, MD.

Rosner, B. 1995. Fundamentals of Biostatistics (4th Edition.) Duxbury Press, Belmont, CA.

Schumacher, R., Neuber, R., Herber, A., Rairoux, P. and Schrems, O. 2001. Extinction profiles measured with a Raman lidar in the Arctic troposphere. In: Advances in Laser Remote Sensing. Proc. ILRC 2000, Vichy, France (eds. A. Dabas, C. Loth and J. Pelon). Ecole Polytechnique, Palaiseau, 229-232.

Sharma, S. 1996. Applied Multivariate Techniques. Wiley, New York.

Shaw, G. E. 1975. The vertical distribution of atmospheric aerosols at Barrow, Alaska. Tellus 27, 39-49.

Shaw, G. E., 1995. The Arctic haze phenomenon. Bull. Am. Meteorol. Soc., 76, 2403-2413.

Shaw, G. E., Stamnes, K. and Hu, Y. X. 1993. Arctic haze-perturbation to the radiation field. Meteorol. Atmos. Phys. 51, 227-235. 
Shiobara, M. 2000. Arctic cloud and aerosol observations using a micropulse lidar in Svalbard, Proc. 1st Int. Workshop on Space-borne Cloud Profiling Radar, Tsukuba, Japan, 179-182.

Sirois, A. and Barrie, L. A. 1999. Arctic lower tropospheric aerosol trends and composition Alert, Canada: 1980-1995. J. Geophys. Res. 104, 11 599-11618.

Skouratov, S. 1997. Vertical profiles of arctic haze aerosol in spring 1994 obtained by using spectrophotometric measurements. Atmos. Res. 44, 113-124.

Smolinski, A., Walczak, B. and Einax, J. W. 2002. Hierarchical clustering extended with visual complements of environmental data set. Chemometr. Intell. Lab. Syst. 64, 45-54.

Spinhirne, J. D. 1993. Micro pulse lidar. IEEE Trans. Geosci. Remote Sens. 31, 48-54.

Stohl, A. 1998. Computation, accuracy and applications of trajectories: a review and bibliography. Atmos. Environ. 32, 947-966.

Ström, J., Umegård, J., Tøseth, K., Turnved, P., Hansson, H. C. et al. 2003. One year observation of particle size distribution and aerosol chemical composition at the Zeppelin Station, Svalbard, March 2000March 2001, J. Phys. Chem. Earth 28, 1181-1190.
Tabanick, B. G. and Fidell, L. S. 1996. Using Multivariate Statistics. Harper Collins College, New York.

Thomason, L. W., Herber, A. B., Yamanouchi, T. and Sato, K. 2003. Arctic study on tropospheric aerosol and radiation: comparison of tropospheric aerosol extinction profiles measured by airborne photometer and SAGE II. Geophys. Res. Lett. 30, 1328-1331, doi:10.1029/2002GL016453.

Wåhlin, P. 2003. COPREM—a multivariate receptor model with a physical approach. Atmos. Environ. 37, 4861-4867.

Wang, P. H., Kent, D. G. S., Veiga, R. E., Yue, G. K., Poole, L. R. et al. 1999. A method for identifying the aerosol-only mode of SAGE II 1.02-um extinction coefficient data at altitudes below $6.5 \mathrm{~km}, J$. Geophys. Res. 104, 9609-9615.

Weller, M., Schulz, E., Leiterer, U., Naebert, T., Herber, A. et al. 1998. Ten years of aerosol optical depth observation at the Lindenberg Meteorological Observatory. Contr. Atmos. Phys. 71, 387400.

Xie, Y. L., Hopke, P. K., Paatero, P., Barrie, L. A. and Li, S. M. 1999. Locations and preferred pathways of possible sources of Arctic aerosol. Atmos. Environ. 33, 2229-2239. 